\title{
INUMAÇÕES INFANTIS EM ÂNFORA NA PENÍNSULA IBÉRICA DURANTE A ÉPOCA ROMANA: A PRÁTICA E O RITO
}

\author{
INFANT BURIALS IN AMPHORAE IN THE IBERIAN PENINSULA DURING \\ THE ROMAN PERIOD: THE PRACTICE AND THE RITUAL
}

\author{
CARLOS PEREIRA \\ FCT, Uniarq, Universidade de Lisboa, Museo de Cáceres. \\ Correo-e: carlos_samuel_pereira@hotmail.com. ORCID: https://orcid.org/0000-0002-4116-3602 \\ PEDRO ALBUQUERQUE \\ FCT, Uniarq, Universidade de Lisboa, Universidad de Sevilla. \\ Correo-e: albuquerque@us.es. ORCID: https://orcid.org/0000-0003-4800-7343
}

\begin{abstract}
Resumo: Apresentam-se neste artigo alguns comentários sobre as inumações infantis em ânfora na Península Ibérica (século I a.C. a V/VI d.C.), bem como um estudo preliminar dos textos romanos e cristãos, escritos durante este período sobre este tema, e ainda a evolução desta prática no registo arqueológico. Definiram-se duas grandes fases: na primeira (antes de $c 250$ d.C.), de formação, surgem alguns casos, e na segunda (depois de $c 250$ d.C.), assiste-se à multiplicação e dispersão deste ritual na Península Ibérica, coincidindo com a expansão do Cristianismo. Outro objectivo deste trabalho é dar resposta a questões sobre as razões que levaram a esta opção: reflecte a reprodução de sistemas simbólicos? Ou razões pragmáticas?
\end{abstract}

Palavras-chave: Inumações infantis; ânfora; Cristianismo; rituais funerários; época romana.

\section{INTRODUÇÃO}

A morte foi sempre um acontecimento que se manifestou das mais variadas formas nas atitudes dos vivos, motivando uma multiplicidade de disposições funerárias. Como algumas das fontes deixam antever, a idade à morte terá sido um dos factores que condicionou estas

\begin{abstract}
This paper presents some commentaries about the infant burials in amphorae in the Iberian Peninsula (1st Century BC-5th Century AD), and a preliminary study of the texts written during this period (both Roman and Christian) about this theme and the evolution of this practice in the Archaeological record. We defined basically two major periods: the first (until c $250 \mathrm{AD}$ ), with some cases (formation), and the second (after $c 250 \mathrm{AD}$ ) with a visible multiplication and dispersion of this ritual along the Iberian Peninsula, almost side-by-side with the expansion of Christianism. Another aim of this paper is to answer some questions about the motivations of this option: it reflects a reproduction of symbolic systems? Or pragmatic reasons?
\end{abstract}

Keywords: Infant burials; amphorae; Christianism; Funerary Rituals, Roman period.

atitudes, podendo ser o funus socialmente mais, ou menos, ostentado.

Entre outros factores, abordados neste trabalho, o registo arqueológico comprova que esta realidade é particularmente variada nos enterramentos infantis. A pluralidade, nestes casos, da localização, da arquitectura, dos ritos e do espólio é verificada quer em 
inumações da mesma faixa etária, quer nas que apresentam idades à morte díspares, mas, sobretudo, de indivíduos impuberis.

Neste sentido, importa estabelecer a definição das idades das crianças na Antiguidade para que, depois, possamos esclarecer se as distintas fases de vida foram preponderantes, ou não, no registo funerário e/ou na visibilidade arqueológica. Além disso, as mesmas fases de vida de uma criança serão comparadas com as definidas pela Antropologia.

Sabe-se, através das fontes, que a vida de um indivíduo romano estava dividida em, pelo menos, três etapas bem definidas (Néraudau 1979: 139): a infância (pueritia), a adolescência (iuventus) e a maioridade (senectus). A cada uma destas etapas a literatura romana associa distintas características e determinadas qualidades (Cícero, De Senectute, 33).

No entanto, esta divisão é bem mais complexa. A infância, etapa que nos interessa particularmente, pode ainda ser subdividida noutras. Um de nós teve oportunidade de referir que, em época romana, as crianças com menos de 40 dias de vida não estavam legalmente protegidas pelo ius pontificium (Pereira 2014a: 413), argumento que foi utilizado para justificar o facto de estes, até aos dois anos, terem sido inumados e não cremados (Lillo 2001-2002: 128). No entanto, e ainda que a inumação tenha sido utilizada para indivíduos de idade superior aos 40 dias, há argumentos suficientes para defender que, antes dos 6/7 meses, o indivíduo não era cremado (Baills-Talbi e Dasen 2008: 598; Carrol 2011: 105; cf. Plin. NAT. 7.72).

Importa, portanto, reter dos textos clássicos informações sobre duas grandes fases da vida de um indivíduo: uma primeira (infans), que dura até aos 7 anos (cf. Var. L. 6.52), e uma segunda (impuber), entre esta idade e os 14 anos. Nesta segunda fase, um indivíduo iniciava a aprendizagem e, caso pertencesse a uma gens influente, começava a ostentar a toga praetexta iniciando a participação na vida familiar, auxiliando o pater familias, pois era já considerado um indivíduo auto-suficiente e com pensamento próprio (embora ainda não livre), tarefas que lhe permitiriam alcançar "la liberté morale" (Dupont 1994: 265).

A partir dos 14 anos, o indivíduo passava a ser considerado puber. Por outras palavras, é o momento em que entrava na vida adulta (Festo, s.u. Pubes), integrando-se oficialmente na vida pública e adquirindo uma determinada liberdade civil. Todavia, esta fase variava consoante o género e a consideração do pater familias. A transição seria aos 12 (caso fosse mulher) e aos 14/16 anos (caso fosse homem). Os indivíduos masculinos deixavam de utilizar a toga praetexta e passavam a portar a toga virilis, abandonando definitivamente a bulla.

A leitura das fontes e da iconografia, nestes casos, é essencial para ter uma ideia sobre o modo como a criança, nas suas várias fases, era vista na sociedade romana ou na própria lei. $\mathrm{O}$ estudo das diferentes fases da vida das crianças, ou as alusões à sua morte, é relevante para uma aproximação aos dados arqueológicos obtidos na Península Ibérica.

A Antropologia, por sua vez, também utiliza as suas próprias nomenclaturas (Lewis 2011: 1, tab. 1), parecendo pertinente verificar até que ponto são coincidentes com as informações textuais. Por exemplo, considera dois tipos de nados-mortos: embrião (cerca de 8 semanas intra-uterinas) e feto ( 8 semanas até ao nascimento). No caso que nos ocupa, e considerando a natureza da maioria dos dados analisados, optámos por utilizar a expressão genérica de nados-mortos, referindo a existência de fetos unicamente quando os dados o permitem.

A partir do nascimento são consideradas duas etapas distintas: neonato (até 30 dias após o nascimento) e pós-neonato (entre 30 dias e 1 ano). Após o ano de idade, a Antropologia considera crianças os indivíduos entre 1 e 14 anos e adolescentes aqueles falecidos entre os 14 e os 17 anos, idade a partir da qual são considerados adultos. Esta divisão está de acordo com a que descrevemos antes, coincidência que permite utilizar conceitos concretos para cada fase da vida em época romana e articular o discurso em torno da seguinte divisão: nado-morto, neonato, infante (até 1 ano de idade) e criança (mais de 1 ano).

A abundância de dados sobre enterramentos infantis levou-nos a circunscrever este estudo aos enterramentos em ânfora. Nesta opção pesou sobretudo a possibilidade de este contentor poder fornecer dados acerca da sua utilização ritual e/ou pragmática, procurando esclarecer algumas questões que a investigação tem vindo a colocar. Além disso, e ainda que a maioria destas sepulturas não contenha espólio, o féretro é, per se, um elemento datante que garante, à partida, um enquadramento crono-cultural.

Entre as várias questões colocadas, pareceu importante procurar explicar o uso de ânforas maioritariamente em enterramentos de indivíduos com idade inferior a 1 ano, bem como o seu possível simbolismo. Neste sentido, o estudo da multiplicidade de contextos funerários deve considerar a elevada mortalidade infantil na Antiguidade, por um lado, e a diversidade de atitudes perante a morte, por outro. 


\section{VIDA E MORTE INFANTIL: REPRESENTAÇÕES LITERÁRIAS E ICONOGRÁFICAS (SÉCS. I A.C.-IV D.C.)}

\author{
"São as mesmas pessoas que pensam que, se um \\ menino pequeno morre, há que suportá-lo com sere- \\ nidade, enquanto que, se morre no berço, nem sequer \\ há que lamentá-lo."
}

Cic., Tusc. 1.39 (Trad. A. Medina, adaptado)

Os textos latinos sobre este tema são, infelizmente, escassos e não raras vezes vagos, condicionando a análise das várias etapas da integração de um indivíduo na sociedade, desde o nascimento até à morte. A caracterização deste processo é importante para o estudo dos enterramentos infantis em ânfora, não obstante as necessárias reservas no momento em que se utiliza a informação escrita para interpretar o registo arqueológico e os sistemas simbólicos (ou pragmatismo) que justificariam a escolha de um determinado ritual fúnebre.

Estamos, à partida, perante um fenómeno que se identifica em vários contextos culturais, inclusive anteriores ao Império, que não serão aqui tratados (cf. Baills-Talbi e Dasen 2008: 598ss., com bibliografia; Kollia 2013). Apesar das limitações impostas à interpretação de um registo parcial (v. infra), é possível apresentar alguns comentários que abarcam a literatura, as leis e a iconografia e que permitem colocar questões ao registo arqueológico.

O tema ganha ainda mais interesse quando se constata que o Cristianismo deu continuidade aos enterramentos infantis em ânfora, associando-se a uma extraordinária multiplicação de casos conhecidos na Península Ibérica, sobretudo a partir do final do século III d.C. Se a chegada de uma nova ideologia reforçou o sentido original do ritual, se simplesmente lhe deu continuidade ou se lhe deu outro significado, são questões às quais procuramos responder com esta contribuição.

Um primeiro aspecto que se destaca das fontes clássicas é o modo como a ânfora pode ser uma representação do útero, simbolizando, por sua vez, um regresso à terra ou um renascimento (Becker 1995: 24; Norman 2002: 310; Stevens 2013: 625-626, 635). A dissecação de animais terá conduzido a essa relação, uma vez que parece ser frequentemente comparado com esse recipiente em posição invertida (Hanson 1990: 321; F. Zeitlin, apud Norman 2002: 310). Por outro lado, a formação da vida no processo de gestação originou várias propostas, não só no que dizia respeito à vertente biológica, mas também a outra questão: quando começa, efectivamente, a vida humana (Dasen 2013: 17).
A representação das fases da vida de um indivíduo parece relacionar-se com esta última preocupação, uma vez que se debatia o momento em que surge a alma em várias correntes da Medicina e da Filosofia antigas (Dasen 2013: 19, com bibliografia; cf. Plin. Nat. 7.187). Até que ponto este aspecto influencia os enterramentos de fetos, neonatos e infantes, tanto em necrópoles ditas "pagãs" como cristãs? Este tratamento pode ser, eventualmente, reflexo da condição social dos indivíduos enterrados ou, por outro lado, do modo como estas almas eram integradas no mundo dos mortos ou, ainda, no mundo dos vivos enquanto entidades do "mais além" (cf. Baills-Talbi e Dasen 2008; Sen. Her. F. 854-857).

A título de exemplo, e numa perspectiva evidentemente poética, o Livro 6 da Eneida (vv. 426-430) apresenta as animae dos infantes ao lado dos condenados injustamente à morte e como entidades que choram por não terem gozado os prazeres da vida e por terem sido afastadas do peito materno. Esta representação pode não reflectir o pensamento da restante população (cf. Vaquerizo 2007: 136-137), mas em todo o caso permite salientar que parece haver aqui um certo sentimento de injustiça perante uma morte prematura. $V$., igualmente, o comentário de Sérvio a Eneida 11, 143 (apud Néraudau 1984: 375-376).

De acordo com vários textos, um indivíduo é infans até aos 7 anos, momento em que começaria a adquirir um pensamento racional (Harlow e Laurence 2002: 3450). Esta era, pelo menos durante o Império e talvez um pouco antes, a ideia dominante. A aprendizagem começava a partir desta idade, i.e., na fase do impuber, que durava até aos 14 anos (cf. Néraudau 1984: 23ss.). A infantia com fim aos 7 anos de idade só foi oficialmente integrada na legislação a partir do século III (p.ex., Modestinus, apud Dig. 23, 1.14; Cuq 1899a; Berger 1991 s.v. infans; cf. a relação entre este aspecto e o infanticídio em Cuq 1899b, com textos sobre este assunto e Dig. 1.5.7, 1.5.26, sobre os direitos da criança que ainda não tinha nascido perante a herança do pai falecido).

Um texto de Plínio (Nat. 7.72) indica que os 7 meses marcavam, por seu turno, a primeira fase da vida de um infans, uma vez que era o momento em que começavam a nascer os primeiros dentes. Por esta razão, o autor assinalou que as crianças com idades inferiores a 6 meses não eram, por norma, cremadas (cf. Norman 2002: 309). Por outra parte, na Sátira 15. 137-139, Juvenal parece confirmar a ideia de Plínio quando refere crianças demasiado jovens para serem cremadas, apesar de não especificar a idade (cf. Ciurana 2009-2011: 207).

Cobrir o cadáver ou os restos da incineração com terra seria outra condição para que o enterramento 
adquirisse o valor de locus religiosus (Cic. Leg. 2.5657; cf. Hor. Carm. 1, 28). Não parece haver aqui qualquer menção à conservação dos dentes, o que novamente permite questionar os motivos que levam à escolha da inumação nestes casos, sobretudo quando se constata que dito ritual está presente em contextos onde a incineração é predominante.

A resposta poderia estar nos textos que referem os dois (ou cada um dos) rituais, mas novamente a análise destas situações esbarra em informações pouco claras, embora as Leis das XII Tábuas indiquem, implicitamente, a convivência dos dois rituais (Cic. Leg. 2.58).

É possível estabelecer com isto uma relação com o os resectum, i.e., a preservação de um fragmento de osso que era depositado na sepultura após a cremação (Cic. Leg. 2.55; cf. Var. L., 5. 23; Bodel 2000: 135; Vaquerizo 2010: 31; 2011: 101)? Esta prática parece dar à terra uma grande importância simbólica (Vaquerizo 2010: 31), o que pode justificar o debate, mantido nos textos, sobre a maior antiguidade da inumação (Plin. Nat. 7. 187; Cic. Leg. 2. 55-56, citando X. Cir. 7.7.25; cf. Hope 2009: 81). Plínio, por seu turno, defendeu que a incineração surgiu como consequência das guerras em lugares remotos, uma vez que os inimigos podiam violar as sepulturas dos soldados mortos em combate (Nat. 7.187). Quer isto dizer que parece haver uma tendência para atribuir um valor simbólico a aspectos pragmáticos.

O estudo da legislação pode fornecer algumas pistas para a análise da representação da morte infantil ou das práticas funerárias, mas nestes casos a regulação parece ser, nas palavras de R. López, "compleja y asistemática" (1997: 105-106), o que constitui uma dificuldade por vezes incontornável. Um exemplo é o facto de existir uma lei como a das XII Tábuas (Cic. Leg. 2.58), que não impedia a inumação de recém-nascidos, com menos de 40 dias, sob alguns edifícios. Esta era conhecida como suggrundaria por Fulgêncio nos finais do século V (cf. Baills-Talbi e Dasen 2008: 600):

Priori tempore suggrundaria antiqui dicebant sepulchra infantium qui necdum quadraginta dies implessent, quia nec busta dici poterant, quia ossa quae conburerentur non erant, nec tanta inmanitas cadaueris quae locum tumisceret; unde et Rutilius Geminus in Astianactis tragoedia ait: Melius suggrundarium miser quereris quam sepulchrum (Expositio sermonum antiquorum, 7).

Note-se que, segundo o Ius Pontificium, estes indivíduos não recebiam tais exéquias (cf. López 1997: 113-114, com outros exemplos de leis; Vaquerizo 2007: 137). Independentemente de isto ser reflexo de uma visão negativa ou positiva da criança, parece evidente que o ritual praticado quando esta morre é, na esmagadora maioria dos casos, uma excepção às normas vigentes, o que pode reflectir ou um mecanismo de controlo/exclusão, ou um estatuto privilegiado (Néraudau 1984: 374-375; Baills-Talbi e Dasen 2008: 601-605).

Todas estas normas não transmitem, porém, os sentimentos de quem perde um filho. Uma vez mais, as fontes são pouco claras e até mesmo contraditórias. Um exemplo extraordinário nesse sentido é o texto de condolências que Plutarco escreveu a Apolónio, em $c 70$ a.C., onde o autor afirma que a morte de uma criança é mais suportável que a de um adulto (Mor. 113d), ideia que também havia sido defendida por Cícero (Tusc. 1.39). Uma passagem de uma carta de Plínio - o - Jovem assinala que Régulo perdeu um filho pouco depois de o ter emancipado (podia ser um impuber, mas o autor não especificou a idade) e que procurou osten$\operatorname{tar}$ (mais do que sentir) a sua dor quando sacrificou animais de estimação e brinquedos diante da pira funerária (Ep. 4, 1-4).

Assim, muitos acabam por seguir a ideia, defendida inicialmente por P. Ariès na década de 60 do século passado, de que havia um desinteresse generalizado pela infância antes do século XVIII e, portanto, uma ausência de luto ou tristeza quando se perdia uma criança (cf. Dasen 2013). A iconografia dos sarcófagos, sobretudo a partir do século II (fig. 1: note-se a representação dos pais; cf. Toynbee 1996: fig. 10), bem como o registo arqueológico, permitem matizar um pouco essa imagem. De facto, assiste-se neste período ao desenvolvimento de mecanismos de apoio às crianças a vários níveis, bem como de protecção dos seus interesses (mais do que os direitos dos pais), revelando a ideia de que a criança era o reflexo da prosperidade de um povo. Quer isto dizer que, provavelmente, passou a ter uma maior consideração social (cf. Rawson 1997: 224226), como parece estar patente nas representações iconográficas das fases da vida de um indivíduo, desde o nascimento até à morte. Exemplo disso é o monumento da Via Portuense, nas imediações de Roma, descoberto em 1949. Neste, destacam-se três episódios: o primeiro banho de uma criança; o momento em que começa a andar e, finalmente, a sua instrução. Estas representações são herdeiras de uma assinalável tradição anterior ligada à exaltação dos feitos do defunto (cf. Kampen 1981: 48ss.).

Acrescentam-se ainda os textos de Plb. 6.53-54 e Dion. Hal. 5.17 sobre a laudatio funebris, que parece ter alguma relação com esta tendência de representação da biografia no registo iconográfico, embora seja, 


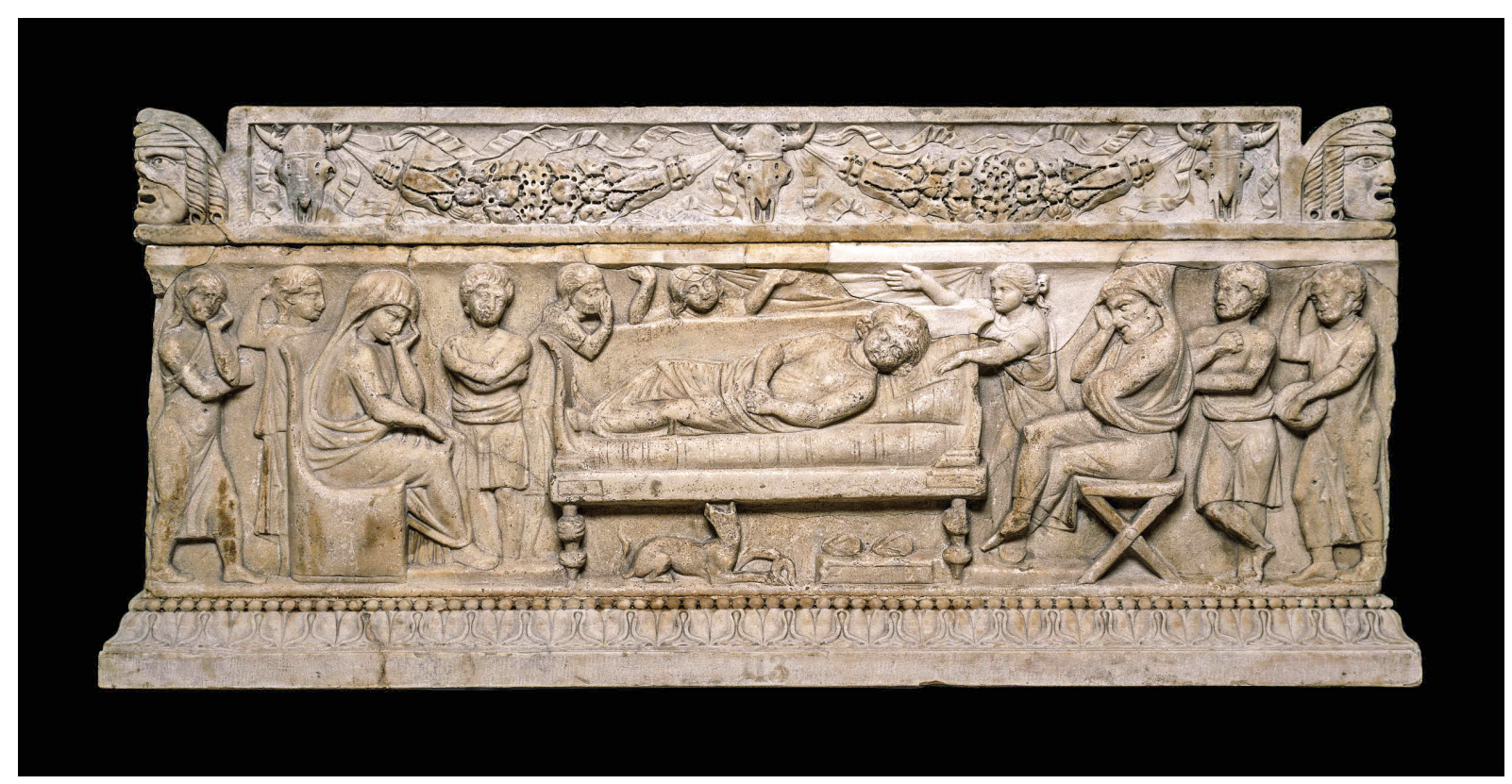

Figura 1. Sarcófago em mármore representando o leito de morte de uma criança (século II). Imagem cedida pelo British Museum (AN301706001).

essencialmente, uma narração verbalmente transmitida (Kampen 1981: 49 e n. 10). Porém, tais exéquias não podiam aplicar-se a crianças, uma vez que um tão curto percurso vital não incluiria elementos que pudessem ser instrumento de memória, até mesmo de consciencialização, daqueles que assistiam às cerimónias

Por último, devemos assinalar a recepção dos textos clássicos nos primeiros tempos do Cristianismo, destacando-se algumas reflexões sobre a alma em textos como Acerca da Alma, de Tertuliano, e a Carta de Agostinho a S. Jerónimo (Jer. Ep. 139), com a mesma temática, dos séculos III e IV. Apesar de não se lhes dedicar, nesta ocasião, o espaço que este tema merece, o seu estudo é fundamental para contextualizar os enterramentos infantis num quadro de referência que dá continuidade, ainda que de um modo muito selectivo, a algumas tradições anteriores. No caso que nos ocupa, sobressai a questão da morte antes do baptismo, momento em que a criança se liberta do "pecado original", e o modo como se questiona a ausência de pecados cometidos por estes inocentes quando morrem (Jer. Ep. 139. 21; cf. Tert. De anim. 56.5). Saliente-se que, do ponto de vista teológico, a alma renasce em Cristo depois, e nunca antes, do baptismo (Jer. Ep. 139. 21-24). Em 1Cor, 15, 22: "E como todos morrem em Adão, assim em Cristo todos voltarão a receber a vida" (cf. Rm. 5, 12ss). Ou seja, debate-se o destino da alma quando esta se separa do corpo ainda em Adão e a morte prematura, nas palavras de Tertuliano (Tert. De anim., 56). É também conhecido um caso de morte prematura numa passagem do segundo livro de Samuel, em que um dos filhos de David morreu ao sétimo dia, como castigo pelos pecados do pai, confessados ao profeta Natan. Este texto permite afirmar que a alma da criança poderia ir para o "outro lado" (2Sam. 12, 13-23, em particular 23).

Poderíamos então perguntar: "E quem sabe a compensação que, no seu juízo secreto, reserva Deus a estes meninos?" (Jer. Ep. 139. 20). Como pensou quem, no seu pranto e luto, sepultou uma criança tão cedo arrebatada à vida? Como se reflectiu isto no registo arqueológico?

\section{AS ÂNFORAS ENQUANTO FÉRETRO: SIMBOLISMO OU PRAGMATISMO?}

A elevada mortalidade infantil na Antiguidade gerou, na opinião de alguns especialistas, uma considerável proliferação de diversas formas de deposição do cadáver, dependendo de factores como a idade ou classe social do defunto (Norman 2002: 310; Dasen 2009: 210), estes, por sua vez, determinantes na escolha do tratamento do cadáver (Carroll 2011: 213ss.). Embora este tema seja importante, pretendemos abordar particularmente as inumações infantis em ânfora na Península 
Ibérica, expondo, de forma geral, o panorama actual sobre este rito.

A mortalidade infantil na Antiguidade era, de facto, bastante elevada. Exemplo dessa realidade é a necrópole suburbana de Quarto Cappelle del Prete, em Roma, onde foi constatada uma percentagem de mortalidade infantil próxima dos 60\% (Catalano et al. 2006). A proliferação de casos que delatam esta realidade, embora nem sempre com percentagens tão elevadas, permitiu defender que cerca de $50 \%$ das crianças nascidas não alcançariam os 10 anos de idade (Hopkins 1966; Néraudau 1984: 373-374; Garnsey 1991: 51-52).

Conquanto estes dados possam ser extrapolados para outros contextos, os resultados dependem, evidentemente, de várias circunstâncias que estão, directa ou indirectamente, relacionadas com a capacidade de resistência dos infantes. Seguramente que nascer no campo não seria equiparável a nascer na cidade, onde o risco de epidemias e doença seria mais elevado; a classe social era também um factor de peso; a alimentação, inicialmente da progenitora e, depois, da própria criança; inclusivamente o clima (estações do ano) representava um risco considerável para a sobrevivência.

Apesar do interesse das percentagens fornecidas pela necrópole escavada em Roma, há que considerar que o registo funerário é, na maioria das vezes, parcial. Além disso, quanto mais prematura a morte de uma criança, menos provável é a conservação da sua estrutura óssea, composta por uma considerável percentagem de cartilagens. Considere-se ainda que a composição sedimentar pode ser determinante (Baker et al. 2005: 11-16), sobretudo se o solo for mais ácido (cf. Lewis 2011: 1-4).

É impossível abarcar neste breve texto a globalidade de um tema destas características, que merece, seguramente, um tratamento monográfico. De facto, se esta temática tem merecido atenção noutras áreas geográficas do Império, como é o caso da Gália (Coulon 2004; Laubenheimer 2004), da Germania (Beilke-Voigt 2008) ou do Norte de África (Norman 2002, 2003), o mesmo não pode ser afirmado para o Extremo Ocidente. Em Portugal, por exemplo, esta temática não tem recebido suficiente atenção.

Assim, circunscrevendo-nos a dois factores importantes, a idade à morte e o contentor fúnebre, limitámos esta análise às inumações infantis em ânforas. A importância deste estudo reside nas informações que o próprio contentor pode fornecer, quer ao nível da datação quer de uma possível relação entre o ritual e o conteúdo primitivo. Neste sentido, identificaram-se exemplares que transportaram vinho, azeite e, em maior número, preparados piscícolas. Isto permite afirmar que a escolha do recipiente e a sua utilização no funus resulta de uma atitude pragmática explicada pelo fácil acesso a ânforas descartadas, ou compradas directamente na figlina, e pelo ajuste da dimensão do recipiente ao inumado.

Se a informação contida nas fontes clássicas pode dar-nos alguma luz sobre as crianças que eram, ou não, cremadas, mais difícil é dissertar acerca dos motivos que fomentaram esta diferença de tratamento do corpo, mesmo quando a cremação era praticada pela maioria da sociedade. Um de nós teve oportunidade de abordar, de forma mais detida, este assunto (Pereira 2014a: 1933), parecendo evidente que a cremação era considerada como um acto de purificação. Não obstante, parece-nos evidente que a cremação era vista simultaneamente como uma acção que solucionava a questão contaminadora do cadáver (deterioração, decomposição), além de que era uma forma prática de deposição dos restos mortais. Era, portanto, um recurso mais higiénico de proceder à destruição da matéria orgânica. Essa consideração parece contradizer o facto de as crianças não terem um estatuto de cidadania e de estarem legalmente desprotegidas. Ainda assim, ambos argumentos podem estar relacionados com o facto de estas não serem consideradas como poluentes, desde que o funus tivesse lugar durante a noite (Rose 1923: 191-194; Lindsay 2000: 156).

É interessante constatar que a idade que Plínio referiu não parece reflectir-se de forma tão taxativa nas necrópoles. Como Mauren Carroll bem evidenciou para os casos italianos, frequentemente se detectam inumações de crianças de idade superior a um ano, quando a cremação era a norma, enquanto outros correspondem a incinerações de infantes (Carroll 2011: 105-106). Assim, ainda que tenhamos dados que permitam supor a existência de normas para a forma de tratamento e deposição do cadáver de crianças e infantes, esses rituais eram, em última análise, elegidos pelos progenitores, acrescentando-se o infanticídio e a exposição infantil quando os filhos não eram aceites pelo pater familias (Smith y Kahila 1992; Grubbs 2013). Devemos ainda considerar que nem sempre os estudos antropológicos permitem atestar com rigor a idade à morte.

Expostas algumas questões que nos pareceram pertinentes sobre o tratamento do corpo, abordando, sobretudo, os motivos que, eventualmente, potenciaram a inumação das crianças quando a cremação era o rito vigente, vejamos agora a forma como estas eram depositadas e quais os féretros utilizados.

Actualmente sabe-se que, para estes enterramentos, eram utilizados os mais variados contentores, além de que o corpo também podia ser directamente depositado 
numa sepultura, inclusive junto a um adulto (fig. 2), em contacto directo com a terra ou sobre um imbrex, selada por simples tegulae. Ainda assim, esta tipologia de sepulturas é mais frequente em crianças jovens (impuberis), sendo os neonatos e infantes depositados em contentores específicos. Infelizmente nem todos os contentores utilizados para este fim se conservaram convenientemente. Os achados de esquifes de chumbo (Vaquerizo 2010: 128, fig. 91) são frequentes, ao contrário dos que foram elaborados com materiais perecíveis. Nestes casos, é comum identificar-se somente os elementos metálicos que os compunham (Pugsley 2003; Ulrich 2007). As sepulturas revestidas com argilas, pedras ou outros materiais de construção, contudo, eram as mais comuns. Esta situação expõe, à partida, questões de difícil resposta, relacionadas com os motivos que justificam esta disparidade de contentores (estatuto social, capacidade financeira da família, maior facilidade de acesso a umas matérias-primas que a outras, etc.). Devemos, por isso, admitir que os resultados desta contribuição não permitem ainda dar resposta a estas interrogações e que estas podem inspirar trabalhos futuros.

No mundo funerário, as ânforas eram igualmente úteis para essa função, além de que também podiam ser utilizadas como material de construção nas sepulturas, nos memoriais e estruturas diversas da necrópole, como parte do espólio votivo, ser utilizadas como marcadores de sepulturas ou servir de canalização para libações vertidas para o interior do sepulcro, desde a superfície. Ainda assim, é frequente a sua utilização enquanto esquife para fetos, neonatos e infantes. Alguns autores consideram que a utilização das ânforas, além do seu simbolismo, serviu também para diferenciar neonatos e infantes de adolescentes e adultos no mesmo espaço funerário (Norman 2003: 40).

Repetindo que a informação que possuímos sobre o mundo funerário em época romana é, na maioria das vezes, incompleta, não arriscamos afirmar categoricamente que as ânforas eram mais utilizadas como esquife, até porque existem exemplos que demonstram que nem sempre assim foi (Monsieur 2006: 145). Ainda assim, a (re)utilização de ânforas para essa finalidade (Sánchez 2006: 193) foi frequente desde a viragem da Era e, sobretudo, a partir da segunda metade do século III d.C. Isso não significa, contudo, que não encontremos contextos funerários mais antigos com presença de ânforas que serviram de féretro para infantes, como acontece em Ibiza (Gómez y Gómez 1989: 221-223) ou na necrópole de Mozia, na Sicília (Delgado y Ferrer 2007: 51), que continham enterramentos infantis em

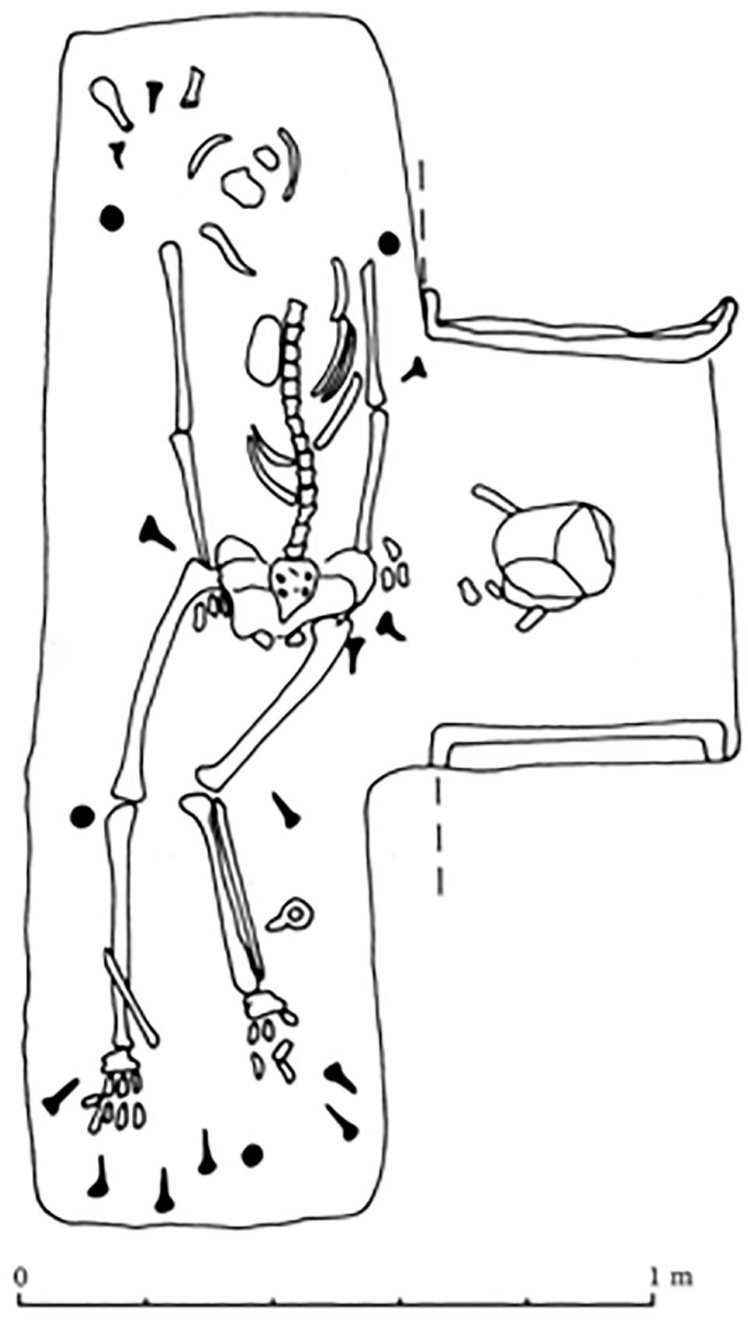

Figura 2. Enterramento de adulto juntamente com um neonato (Gubbio, Itália), segundo Carroll 2011: fig. 3.

ânfora anteriores à presença romana. Esta prática está, ainda, bem documentada em Cartago, entre os séculos IV e II a.C. (Benichou-Safar 1982: 65-68).

Apesar de dispormos hoje de uma bibliografia relativamente abundante sobre a morte infantil, os estudos dedicados exclusivamente às inumações de infantes em ânforas são menos frequentes do que seria desejável. A referência a essa tipologia de enterramentos, anterior à presença romana, pretende apenas demonstrar que este rito já era praticado. Por outro lado, também podemos encontrar raros casos de inumações adultas em ânforas (Dupré i Raventós et al. 1987), situação que já foi abordada antes por um de nós (Pereira 2014a: 415), impondo-se uma distinção entre "enterramento em ânfora" e “enterramento com ânfora(s)". 
Igualmente raros são os espaços funerários destinados exclusivamente a crianças. De facto, temos conhecimento de alguns contextos dessa natureza, que corroboram a variedade de situações e que nos obriga a ser cautelosos no momento em que analisamos o processo de tratamento e deposição de crianças falecidas. Em El Djem (Tunísia), foi escavada uma necrópole que recebeu crianças até uma idade máxima de 15 anos, com especial incidência daqueles que faleciam antes dos três anos (Slim 1983; Norman 2003: 40-41). Esta situação também é conhecida na Península Ibérica, concretamente em Cádis (Alarcón 1993; Lagóstena 2001: 116), onde foi intervencionada uma necrópole que incluía apenas crianças (22 enterramentos), das quais 19 foram inumadas em ânforas, sobretudo nos séculos IV e V d.C.

Embora a arquitectura funerária subterrânea, no caso de neonatos e infantes, seja bastante variada, a (re) utilização de ânforas enquanto contentor fúnebre foi, de facto, uma prática comum na Antiguidade. Não é fácil, porém, discernir o simbolismo que está por detrás da sua eleição ou se esse simbolismo era acompanhado por um pragmatismo que pretendia simplificar o processo fúnebre. Somos de opinião que, como veremos adiante, ambas situações podem ser defendidas. Tal obriga a que, pelo menos sem que tenhamos outros argumentos, sejamos cautelosos sobre a possível utilização ou reutilização destes recipientes, pois a sua maior evidência em sítios próximos a zonas de produção anfórica inviabiliza um esclarecimento evidente.

É momento de relembrar o que foi dito sobre as informações dos textos relativamente ao enquadramento legal e social da criança no mundo romano (Baills-Talbi e Dasen 2008: 598; Carrol 2011: 105; Pereira 2014a: 413), por um lado, e a relação simbólica que é possível estabelecer entre o útero materno e a ânfora, por outro (Becker 1995: 24; Norman 2002: 310; Stevens 2013: 625-626; 635). Não parece que tal analogia seja descabida: se os romanos frequentemente procuravam representar a sua última morada como se da sua própria casa em vida se tratasse (Wallace-Hadrill 2008), faz sentido que também o tenham feito para os infantes falecidos, que, neste caso, eram devolvidos a um estágio de desenvolvimento anterior. Se considerarmos que a frequente abertura existente na ânfora se destinava ao renascimento, como acontece nas necrópoles norte africanas (Stevens 2013: 635), talvez possamos considerar que a colocação do féretro no subsolo simbolize a fertilidade da terra, facilitando assim o renascimento. Por outras palavras, a morte imita, em parte, a vida.
Mais difícil é justificar, como vimos, a relação idade/local de enterramento. Não é fácil interpretar os enterramentos de nados-mortos no subsolo das casas, dentro do pomerium, situação que contrariava, como vimos, a legislação (Cic. Leg. 2.58; Gisbert y Senti 1989: 107-108). Tivemos oportunidade de comentar que este comportamento excepcional pode reflectir mecanismos de exclusão, controlo ou um estatuto privilegiado. Embora seja difícil comprovar tal divisão, já defendida por outros autores (Norman 2002: 310; Dasen 2001: 208211; Stevens 2013: 625 e ss.), existe efectivamente um padrão: fetos ou nados-mortos, sepultados frequentemente sob as casas; infantes, em necrópoles ou espaços próprios depositados em féretros (entre os quais as ânforas, quadro 1); crianças (particularmente a partir dos 7/10 anos), colocados em necrópoles e com sepulturas de arquitectura idêntica à dos adultos.

Atendendo a esta realidade, faria sentido que esta simbologia fosse aplicada nos dois primeiros casos, particularmente no primeiro. Todavia, esta divisão não pode ser entendida como uma norma rígida. Ainda que saibamos que os enterramentos de fetos ou neonatos no interior das casas se devia a que não eram ainda reconhecidos pela sociedade, nem pela legislação da época (sobretudo durante o Alto-Império), seria de supor que estes estariam acomodados quase exclusivamente em ânforas ou recipientes cerâmicos. Sabemos igualmente que o tratamento dado ao cadáver dependia, nestes casos, da consideração e condição dos progenitores, situação que fomentou realidades extremamente contrastantes, recordando que frequentemente eram simplesmente descartados. Um bom exemplo foi a descoberta de um elevado número de nados-mortos em Ashkelon (Israel), que gerou, inclusive, teorias de infanticídio (Smith y Kahila 1992: 667-672), mas que, na realidade, correspondiam a nados-mortos ou abortos descartados (Dasen 2011: 210). De facto, a prática de abortar era frequente em época romana, comprovada por alguns estudos (Prioreschi 1995: 77-87; González Gutiérrez 2015: 138-139), terminando a maioria dos fetos em lixeiras ou canalizações de escoamento de águas.

É, no entanto, nas necrópoles que podemos encontrar o maior número de enterramentos infantis depositados no interior de ânforas. Podemos com isto afirmar que, do ponto de vista "espiritual", dita reutilização pode ter sido um instrumento eficaz para ajudar à superação da dor dos progenitores. Tal não anula, porém, algum pragmatismo que pode estar subjacente a este rito. Note-se, a título de exemplo, que estes enterramentos se concentram sobretudo em lugares onde se fabricavam ânforas, i.e., em sítios onde ditos recipientes eram 


\begin{tabular}{|c|c|c|c|}
\hline $\begin{array}{c}\text { Sepultura } \\
\mathrm{N}^{\mathrm{o}}\end{array}$ & $\begin{array}{c}\text { Desenvolvimento } \\
\text { da coroa }\end{array}$ & Dente & $\begin{array}{c}\text { Intervalo de } \\
\text { idade (meses) }\end{array}$ \\
\hline 1 & $\operatorname{Cr} 1 / 2$ & $\mathrm{c}$ & $3-3,5$ \\
\hline 2 & $\mathrm{Cr} 1 / 2$ & $\mathrm{~m} 1$ & $2-2,5$ \\
\hline 3 & $\mathrm{Crc}$ & $\mathrm{m} 2$ & 7 \\
\hline 4 & $\mathrm{Cr} 1 / 2 \mathrm{Cr} 3 / 4$ & $\mathrm{c} \mathrm{m} 1$ & $3-3,53$ \\
\hline 5 & $\mathrm{Cr} 1 / 2$ & $\mathrm{~m} 1$ & $2-2,5$ \\
\hline 6 & $\operatorname{Cr} 1 / 2$ & $\mathrm{~m} 1$ & $2-2,5$ \\
\hline 7 & Coc & $\mathrm{m} 2$ & 2 \\
\hline 8 & $\mathrm{Cr} 1 / 2$ & $\mathrm{~m} 1$ & $2-2,5$ \\
\hline 9 & $\operatorname{Cr} 1 / 2$ & $\mathrm{c}$ & $3-3,5$ \\
\hline 10 & $\mathrm{Coc} \mathrm{Cr} 1 / 2$ & $\mathrm{c}$ & $1,8-3,5$ \\
\hline 11 & & & feto \\
\hline 12 & A $1 / 2$ & $\mathrm{c}$ & $24-36$ \\
\hline 13 & $\mathrm{Cr} 1 / 2 \mathrm{Cr} 1 / 2$ & $\mathrm{c} \mathrm{m} 1$ & $1,8-3,52-2,5$ \\
\hline 14 & & & $2-2,5$ \\
\hline 15 & Coc $\mathrm{Cr} 1 / 2 \mathrm{Cr} 1 / 2$ & $\mathrm{c} \quad \mathrm{m} 1$ & $1,8-3,52-2,5$ \\
\hline 16 & Coc $\mathrm{Cr} 1 / 2 \mathrm{Cr} 1 / 2$ & $\mathrm{c} \mathrm{m} 1$ & $1,8-3,52-2,5$ \\
\hline 17 & $\mathrm{Cr} 1 / 2$ & $\mathrm{c}$ & $3-3,5$ \\
\hline 18 & $\mathrm{Coc} \mathrm{Cr} 1 / 2$ & $\mathrm{c}$ & $1,8-3,5$ \\
\hline 19 & $\mathrm{Cr} 1 / 2$ & $\mathrm{c}$ & $3-3,5$ \\
\hline 20 & $\mathrm{Coc} \mathrm{Cr} 1 / 2$ & $\mathrm{c}$ & $1,8-3,5$ \\
\hline
\end{tabular}

Quadro 1.Determinação daidade, em meses, dos enterramentos infantis de Chipiona a partir do desenvolvimento das coroas dentais, segundo Alcázar et al. 1994 (adaptado). Apenas se documentou um caso que excede o ano de idade.

mais facilmente adquiridos, o que em boa medida justifica o contraste que neste aspecto se constata entre o litoral e o interior, como veremos no próximo capítulo.

\section{DISPERSÃO DE INUMAÇÕES EM ÂNFORA NA PENÍNSULA IBÉRICA}

Os dados conhecidos até ao momento para a Península Ibérica integram-se num fenómeno que foi reconhecido um pouco por todo o Mediterrâneo (Stevens 2013). No entanto, antes de traçarmos um panorama geral da realidade peninsular, importa tecer algumas considerações sobre cada local onde apareceram enterramentos desta tipologia (fig. 4 e 5), de modo a reconstituir, dentro das naturais limitações, uma leitura diacrónica que identifique a introdução e a disseminação deste rito. Devemos sublinhar, contudo, que o facto de a divulgação científica destes contextos ser amiúde pouco exaustiva, resultante de publicações breves ou integrada em contribuições que incidem sobre outras questões, impede a obtenção de respostas às interrogações que este estudo pode colocar. A isto junta-se a frequente ausência de informações sobre os dados antropológicos e a classificação dos contentores. Mesmo assim e ainda que a título provisório, podemos apresentar um esboço de uma (possível) diacronia, assim como colocar algumas questões para as quais, insistimos, não garantimos esclarecimentos taxativos.

\subsection{Os primeiros enterramentos em ânfora de época romana (séculos I a.C.-III d.C.)}

O caso mais antigo conhecido, até ao momento, localiza-se no levante peninsular, concretamente na necrópole de La Calle Quart, em Valência (García Prósper et al. 2002-2003: 282; García Prosper 2015: 584). Aí foi documentado um único caso de enterramento infantil em ânfora, datado do século I a.C., que conviveu quer com o rito de cremação quer com o de inumação. Em Valência esta coexistência parece estar documentada desde o momento fundacional da cidade (138 a.C.) (Vaquerizo 2007a: 173-174), onde a cremação é predominante somente durante o século I a.C. (García Prósper et al. 2002-2003: 282; Ribera i Lacomba 2010), momento em que esta inumação infantil em ânfora foi praticada. Infelizmente não conhecemos, por ora, quaisquer dados acerca da tipologia da ânfora ou idade do inumado.

A esta necrópole junta-se outra (quadro 2), desta vez em Cádis, com 63 sepulturas intervencionadas, onde se registou uma realidade funerária idêntica. Localiza-se na Calle García Carrera e foi datada, grosso modo, dos séculos I a.C. e I d.C. (Córdoba y Belizó 2010: 437). Foi igualmente constatada a convivência dos ritos de cremação e inumação, assim como a presença de um caso de inumação infantil em ânfora. A análise deste enterramento não está isenta de problemas: por um lado, não se sabe ao certo a idade do inumado e, por outro, a datação que lhe foi atribuída é bastante ampla. No entanto, os autores integraram o contentor na forma Dressel 7/11, o que permite supor uma cronologia da primeira metade do século I d.C. (García y Bernal 2008: 664-668) para este enterramento. 
Em local próximo, mas suficientemente distante para julgar que se trata de áreas funerárias diferenciadas, foi intervencionada outra necrópole que albergava sepulturas pré-romanas e romanas (Sibón et al. 2007: 148). Nesse espaço foram registadas duas sepulturas infantis em ânfora, desconhecendo-se a idade à morte dos inumados. Todavia, os autores fazem referência a contentores anfóricos dos tipos Dressel 20, 7/11 e 12 (Sibón et al. 2007: 151), o que obriga a supor que alguma das sepulturas utilizou duas ânforas distintas. Caso os féretros correspondam às duas últimas ânforas, é aceitável defender, tal como no caso anterior, uma datação dos enterramentos ainda na primeira metade do século I d.C., dependendo a restante da variante em que se integra.

De momento, estes são os únicos casos que permitem apresentar com segurança uma datação anterior a meados do século I d.C., e que coincidem, mais do que na cronologia, nos ritos executados. A partir de meados dessa centúria, a multiplicação de casos conhecidos testemunha a disseminação deste rito nas principais cidades meridionais e levantinas, tal como nos casos anteriormente expostos.

No que respeita ao Levante (fig. 4), somente na área alicantina e valenciana se documentaram enterramentos infantis em ânforas. Já González Villaescusa (2001: 80) havia notado a pouca quantidade de sepulturas infantis na zona valenciana, mormente as que utilizaram ânforas como féretro, situação que se manteve até à actualidade. Porém, estamos convencidos de que esta realidade pode resultar da falta de divulgação de dados referentes a esta temática, pois os poucos casos conhecidos foram registados em contextos habitacionais, ou são transmitidos em notícias curtas, desconhecendo-se a realidade funerária infantil das necrópoles urbanas.

Ainda que se conheçam notícias de contextos funerários onde se documentaram sepulturas infantis em ânforas (Lamboglia 2, Dressel 1 e Dressel 2-4), concretamente em La Boatella (González Villaescusa 2001: 226-227), em Portal de Russafa (ibidem: 235) ou em Les Foies (ibidem: 282-283), estes correspondem a informações antigas nem sempre de consensual interpretação. Ainda assim, estas devem ter-se em conta, sobretudo porque documentam um momento em que este rito não era praticado de forma recorrente.

Todavia, a dificuldade em interpretar os dados de trabalhos arqueológicos antigos está particularmente patente na necrópole de La Boatella, onde se supõe que a utilização dos contentores funerários mais antigos (Lamboglia 2 e Dressel 2-4) foi contemporânea à dos mais recentes (Almagro 51c). A possibilidade de que ânforas de tipo Lamboglia 2 e Dressel 2-4 tenham sido utilizadas em cronologia coevas à das Almagro 51c não parece fazer muito sentido, sobretudo se tivermos em conta que tal realidade não está documentada em outros contextos.

Além destes casos levantinos que, embora tenham oferecido contentores de cronologias antigas, não são fáceis de interpretar, conhecem-se ainda enterramentos subgrundales em Denia, Alicante (Gisbert y Senti 1989). Trata-se, porém, de contextos fundacionais relacionados com a construção de um horreum, onde se fizeram sepultar quatro fetos/nados-mortos no interior de ânforas de tipo Dressel 2-4.

A leitura deste caso é particularmente difícil, uma vez que até então os enterramentos no interior de edifícios de armazenamento eram desconhecidos. Podemos questionar se a escolha do local de enterramento é simbólica, sobretudo se equipararmos esta opção aos enterramentos no interior dos espaços de habitação. Refira-se ainda que quando se detectam enterramentos no interior das casas estes costumam ser posteriores à sua edificação; contudo, os que foram descritos pelos autores são atribuídos à fundação do edifício e articulam-se com este. Ainda que este caso represente diferenças significativas no que diz respeito ao tipo ou funcionalidade do edifício, não deixa de reproduzir a tendência de enterrar no interior de estruturas fetos ou nados-mortos.

Se na área levantina os enterramentos infantis em ânfora não parecem ter sido abundantemente praticados durante o Alto-Império, o mesmo não pode ser afirmado para a Bética. Conquanto este rito não seja quantitativamente abundante, apresenta uma dispersão considerável constatada, sobretudo, em necrópoles urbanas.

Em Córdoba apareceram enterramentos em ânfora nas intervenções das calles El Avellano, Beatriz Enríquez e La Constancia (fig. 3). Trata-se de espaços funerários distintos, mas próximos, de Colonia Patricia Corduba e que, possivelmente, integram a necrópole Setentrional (Moreno 2006: 236). Na calle El Avellano foi exumada uma inumação infantil que estava acondicionada no interior de uma ânfora de tipo Beltrán IIB (Penco 1998: 66). O autor datou este enterramento da primeira metade do século I d.C., baseando-se na tradicional cronologia que vinha sendo atribuída a esta ânfora. Todavia, uma revisão dos contextos em que apareceram estes recipientes, publicado nesse mesmo ano (García Vargas 1998: 110), permitiu avançar o início da produção desta forma para época cláudia ou mesmo flávia. Assim, parece conveniente considerar este enterramento também posterior a essa cronologia. 




Figura 3. Localização dos contextos onde apareceram enterramentos infantis em ânfora, Córdoba (necrópole Setentrional), com indicação das muralhas romanas imperiais. 1.- Calle El Avellano; 2.- Calle Beatriz Enríquez. Adaptado a partir de http://www. arqueocordoba.com/ arqueosig/\#15/37.8864/4.7784 (cons. 5/02/2018).



À semelhança de outros casos apontados, estamos perante um enterramento infantil identificado numa necrópole onde conviveu incineração e inumação, e onde também foram enterrados adultos. No entanto, e ainda que se denote uma considerável presença de enterramentos infantis (5 de um total de 9), esta vem sendo considerada uma área funerária destinada a escravos e libertos. Os argumentos esgrimidos para apoiar tal hipótese são fundamentalmente dois: a desorganização espacial da necrópole e a recolha de memoriais durante a intervenção, aparentemente sem adscrição sepulcral, com presença de onomástica de origem grega nos epitáfios (Penco 1998: 70-71; Ruiz 2009: 62, p.e. Myrinus ou Pomponia Sime).

Distinta realidade, porém, é desvendada pelos dados da calle Beatriz Enríquez. Esta intervenção, que flanqueia com a que decorreu na fábrica La Constancia, proporcionou o registo de uma área funerária exclusiva de neonatos e crianças prematuras (68 enterramentos), dos quais cerca de um terço foi inumado em ânforas (Moreno 2006: 238). Esta considerável concentração de sepulcros infantis, efectuados durante pouco menos de um século, foi alvo de distintas interpretações apoiadas em uma mortalidade infantil elevada, destacando-se ser o resultado de práticas rituais (Vaquerizo 2001: 152) ou de epidemias (López 2004: 55 apud Ruiz 2009).

Este contexto, datado do século I d.C. com base nas ânforas utilizadas como féretro (Dressel 7/11 e Haltern 70 béticas), corresponde a um dos poucos conhecidos dedicado exclusivamente a enterramentos infantis. Todavia, devemos ter em conta que esta intervenção não corresponde à totalidade da necrópole setentrional desta cidade bética. Partindo dos contextos escavados na calle El Avellano e em La Constancia, é possível considerar que este espaço dedicado a enterramentos infantis representa um sector diferenciado da necrópole setentrional. Por outro lado, se tivermos em conta que estes enterramentos foram efectuados durante cerca de um século e que os índices de mortalidade na Antiguidade eram, como vimos, elevados, não surpreende tanto a grande quantidade de sepulcros. Ademais, esta informação deve ser comparada com a quantidade total de enterramentos da necrópole setentrional. Somente assim se poderá vislumbrar se o índice de mortalidade infantil é, efectivamente, elevado. 
Na contígua intervenção da Fábrica de la Constancia identificaram-se 50 sepulturas de incineração e 3 de inumação (Vaquerizo 2001: 189-190), das quais uma estava coberta por fragmentos de ânfora (cf. Vargas 2002: 198). No entanto, as publicações dos resultados desta intervenção nem sempre permitem estabelecer uma distinção clara entre enterramentos com cobertura de ânfora e com cobertura de fragmentos de ânfora (cf. Sánchez 2006: 193), o que dificulta a sua interpretação.

Mais uma vez, estamos perante um sector distinto da necrópole setentrional da cidade onde foram edificados recintos funerários que receberam, principalmente, incinerações (Vaquerizo 2001). Esta diferenciada funcionalidade destes sectores corrobora a dinâmica desta necrópole, em que determinados espaços estavam destinados a determinadas classes ou a determinadas faixas etárias.

Córdoba não foi a única cidade que praticou este rito. Mais a Sul, mas também no interior, foram documentados três casos de enterramentos infantis em ânfora na cidade bética de Colonia Augusta Firma Astigi (actual Écija). As ânforas correspondem a formas cronologicamente integráveis no século I d.C., concretamente dos tipos Dressel 20 e Beltrán IIB de produção bética (Aguilar Camacho 2004: 895; Tinoco Muñoz 2004: 912).

Uma vez mais, na necrópole de La Algodonera, em Écija (fig. 4), a inumação convive com a incineração. A utilização de ânforas neste sítio é, aliás, bastante comum, a julgar por uma sepultura de incineração com cobertura de ânfora (enterramento 3) e pela deposição de uma incineração infantil no interior de uma ânfora de tipo Dressel 20 (Aguilar Camacho 2004: 895, enterramento 11). Outros dois enterramentos (20 e 21) correspondem a inumações acomodadas em ânforas de tipo Beltrán IIB (Tinoco Muñoz 2004: 916).

Embora na maioria dos casos os bordos das ânforas fossem descartados, para colocar o cadáver no interior do recipiente cerâmico, nesta necrópole eram reaproveitados para construir canalizações que conduziam as libações para o interior dos sepulcros (ibidem: 912). Deve salientar-se, porém, que esta situação é fomentada pelo âmbito crono-cultural em que se realizam os enterramentos. Como veremos adiante, os enterramentos infantis são particularmente prolíferos a partir do século III d.C., sobretudo num momento avançado dessa centúria, altura em que a inumação era praticamente o rito vigente e em que as libações haviam caído em desuso.

Além dos contextos documentados em Cádis (Córdoba y Belizó 2010: 437), também nas cidades litorais de Baelo Claudia e Onoba foi registado este rito. Nesta apenas foi recuperada a ânfora (enterramento 2), que já não continha qualquer material osteológico uma vez que o seu interior havia sido utilizado por roedores (Castilla et al. 2003: 506). Apesar de os autores não fornecerem informações concretas sobre o tipo de ânfora utilizado, é possível que corresponda à forma Beltrán IIB, considerando os bordos (condutos de libações) retirados das ânforas utilizadas como féretros infantis.

Em Baelo Claudia temos conhecimento de que, durante o século I d.C., se praticaram inumações infantis (Paris et al. 1926: 87 apud Vaquerizo 2010: 176). Todavia as informações não são esclarecedoras quanto à cronologia exacta e aos contentores utilizados para esse fim. Efectivamente, o recente trabalho de F. Prados (2015: 109) questiona a existência de inumações anteriores a esse momento, pois as recentes intervenções não permitiram tais registos. Todavia, um de nós já alertou para o facto de a transição de um para outro rito (cremação/inumação) ser um fenómeno que ganha contornos distintos, por vezes dispares, de região para região (Pereira 2014a: 433-435).

Devemos ainda considerar dois outros casos conhecidos em Málaga, um documentado na intervenção de Paseo de los Tilos e o outro na do Barrio de la Trinidad, ambas localizadas a ocidente da cidade romana e na margem oposta ao rio Guadalmedina. No último caso foi exumada uma inumação infantil em ânfora de tipo Beltrán IV que o autor datou entre os séculos I e III d.C. (Melero 2009: 2438). Embora tudo aponte para uma sepultura isolada, já que não foram detectados outros sepulcros associados a este, outras sepulturas foram descobertas na zona (Vaquerizo 2007: 388). A compilação dos dados dessas intervenções permite, portanto, falar com segurança de um espaço funerário organizado, o qual seria posteriormente atravessado, tal como noutros casos do mundo romano, por uma das vias que dava acesso à cidade.

A intervenção de Paseo de los Tilos, ainda que tenha oferecido um único caso de inumação infantil em ânfora, do tipo Beltrán VI, reveste-se de importância uma vez que esta área funerária se localizava próximo a uma figlinae da zona malaguenha (Vaquerizo 2007: 394). Esta situação obrigou a considerar que, apesar da proximidade, talvez não correspondesse a uma necrópole urbana, estando destinada a uma classe humilde que residiria na área suburbana, motivo que explicaria a quase ausência de espólio. Este espaço funerário apresenta duas fases, integrando-se o enterramento que nos interessa na fase mais antiga, datada entre início do século II e início da centúria seguinte. 




1- Barcelona; 2- Dénia; 3- Villajoyosa; 4- Málaga; 5- Córdoba; 6- Écija; 7- Tarifa; 8- Cádis; 9- Huelva; 10- Valencia.

Figura 4. Dispersão dos contextos de enterramentos infantis em ânfora na Península Ibérica (Séculos I a.C. a III d.C.) Mapa de base Global Multi-Resolution Topography (alterado).

$\mathrm{Na}$ costa catalã, identificou-se uma inumação de um indivíduo (de $c$ de 18 meses) em ânfora na necrópole de Barcino (actual Barcelona). A cronologia do enterramento (meados do século II-meados do século III d.C.) é idêntica à de Paseo de los Tilos, embora J. Beltrán de Heredia Bercero se incline mais para a terceira centúria. O contentor, de produção africana, foi classificado pela autora como "ánfora Byzacena", tipo africana "piccola" (Beltrán de Heredia Bercero 2007: 30).

Este é, até ao momento, o único caso documentado que assegura uma reutilização de um contentor, pois trata-se claramente de uma importação. De facto, até aqui a maioria dos contentores utilizados para inumar infantes apresentam características petrográficas, segundo as classificações de cada autor, que apontam para uma proveniência local/regional. Essa situação é sobretudo evidente, como vimos, no caso da necrópole malaguenha, localizada nas proximidades de uma figlinae. São bem conhecidas as actividades ceramistas em época romana por toda a costa meridional (v. as actas do Congresso internacional, Figlinae Baeticae: talleres alfareros y producciones cerámicas en la Bética romana), situação que seguramente alentou a utilização desses recipientes para a inumação de crianças falecidas prematuramente e, inclusive, para a cobertura de adultos e para a construção de condutos para libações. 


\subsection{Difusão dos enterramentos em ânfora (séculos IV-VI d.C.)}

Se até ao século III d.C. não se conhecem muitos casos de inumações infantis no interior de ânforas, totalizando cerca de 19, o mesmo não se pode afirmar para os contextos funerários dos séculos IV e V d.C. Segundo os dados actualmente disponíveis, contabilizaram-se mais de 400 casos a partir desse momento ( $v$. quadro 3). Desde logo é evidente que esta realidade não pode ser justificada por um incremento produtivo de contentores anfóricos, impondo-se assim outras questões que esclareçam os motivos que levaram ao crescimento exponencial deste rito na Antiguidade.

Neste sentido, e ainda que não hesitemos em atribuir à actividade ceramista um fomento da utilização de ânforas como contentor fúnebre, comprovado pela distribuição deste rito na Península Ibérica (fig. 5), esta realidade não é argumento suficiente para apoiar a difusão destes enterramentos. Assim, não podemos deixar de relacionar estes factos com o avanço do Cristianismo, a partir de finais do século III e inícios do século IV d.C. Todavia, devemos ser cautelosos, pois mais que uma associação desta religião a uma maior preocupação com o destino das crianças falecidas prematuramente e também com a alma (v. supra), esta discrepância pode ser atenuada caso este rito se tenha vulgarizado. Somente se compararmos a totalidade de enterramentos infantis de um e de outro período, indistintamente do rito de deposição do cadáver, poderemos confirmar esta situação. Por outro lado, deve ter-se igualmente em conta que o século III d.C. foi frequentemente transmitido como um sinónimo de crise económica e social que, para alguns autores, se prolongou até época tardia (Fernández 1982). Vejamos, sem que sejamos exaustivos, quais os casos conhecidos na Península Ibérica.

Também nesta fase as cidades litorais foram as protagonistas na utilização desta prática, como é o caso de Ampúrias, de Barcelona, de Tarragona, de Alicante, de Múrcia, de Cartagena, de Málaga, de Cádis, de Huelva ou de Faro. Começando pela costa catalã, em Ampúrias foram exumadas cerca de 46 ânforas que acomodaram inumações infantis (Almagro 1955; Augustí i Farjas et al. 2000). Infelizmente desconhecemos qual seria a idade à morte dos inumados nessas necrópoles Necrópole de Estruch, de Martí y Ballesta Rubert e necrópole de Roses. As ânforas utilizadas para esse efeito foram integradas nas formas Keay XXV, LI, LIII, LIV, LV, LXII e LXXXV (Augustí i Farjas et al. 2000: 48 e $56)$, sendo estes contextos datados pelos autores dos séculos IV e V d.C.
Em Barcelona identificaram-se contextos desta natureza, nomeadamente em Santa Caterina, com 6 enterramentos em ânforas de tipos Keay IV, XIX (Almagro 51 A-B), XXIVA e XXV. Na necrópole da Avenida Cambó, por seu turno, identificaram-se 30 enterramentos infantis, datados dos séculos IV e V d.C., alojados em ânforas africanas das formas Keay IIIB, IV, V, XXV, XXVII, ânforas béticas das formas Keay XIX (Almagro 51 A-B) e ânforas orientais do tipo Keay LIV, datadas dos séculos IV e V d.C. (Beltrán de Heredia Bercero 2010: 374). Novamente reparamos que, seguramente, estas ânforas foram reaproveitadas, pois o facto de serem originárias de áreas tão distantes, como é o caso do Norte de África, não permite afirmar que tenham sido compradas directamente ao artesão que as terá produzido e inviabiliza que tenham chegado vazias a este destino.

Em Tarragona o número de casos é igualmente significativo. No Parc de la Ciutat, contexto também conhecido como necrópole de Francolí, foram identificados 38 enterramentos em ânfora (fig. 6), sobretudo do tipo Keay XIX (Almagro 51 A-B) (Dupré i Raventós et al. 1987: 114-115), datados entre final do século III e primeira metade do V d.C. Igualmente correspondente à grande necrópole ocidental de Tarraco (Gurt y Macías 2002: 92-94) deverão ser os contextos identificados na intervenção do Prat de la Riba (Foguet e Vilaseca 1995: 158), ainda que estes apresentem uma datação ligeiramente mais recente.

Até ao momento esta é das poucas necrópoles onde se detectou uma quantidade considerável de enterramentos em ânfora de adultos. Embora este rito não seja comum em adultos, a necrópole ocidental de Tarraco demonstra que foi, apesar de tudo, praticado, motivo pelo qual não excluímos a existência de outros casos, sobretudo na costa mediterrânea oriental. Para esse efeito, atendendo à maior dimensão dos inumados, foram utilizadas até quatro ânforas, seccionadas e depois novamente unidas. Ainda assim, surpreende a existência de apenas 9 casos de enterramentos infantis dos 38 identificados.

Devemos ainda somar a estas intervenções a que ocorreu na calle Jaume I, onde foram registados três enterramentos em ânfora de um neonato e dois infantes. Estavam acomodados em ânforas de tipo Africana II, Keay XXVIIB e de tipo Emporitano, o que permitiu datações do século IV e primeira metade do V d.C. (García y Remolà 2000: 167). Conquanto esta intervenção tenha ocorrido numa área mais afastada em relação à que corresponderá à da necrópole ocidental, pode ser considerada parte do mesmo espaço. 


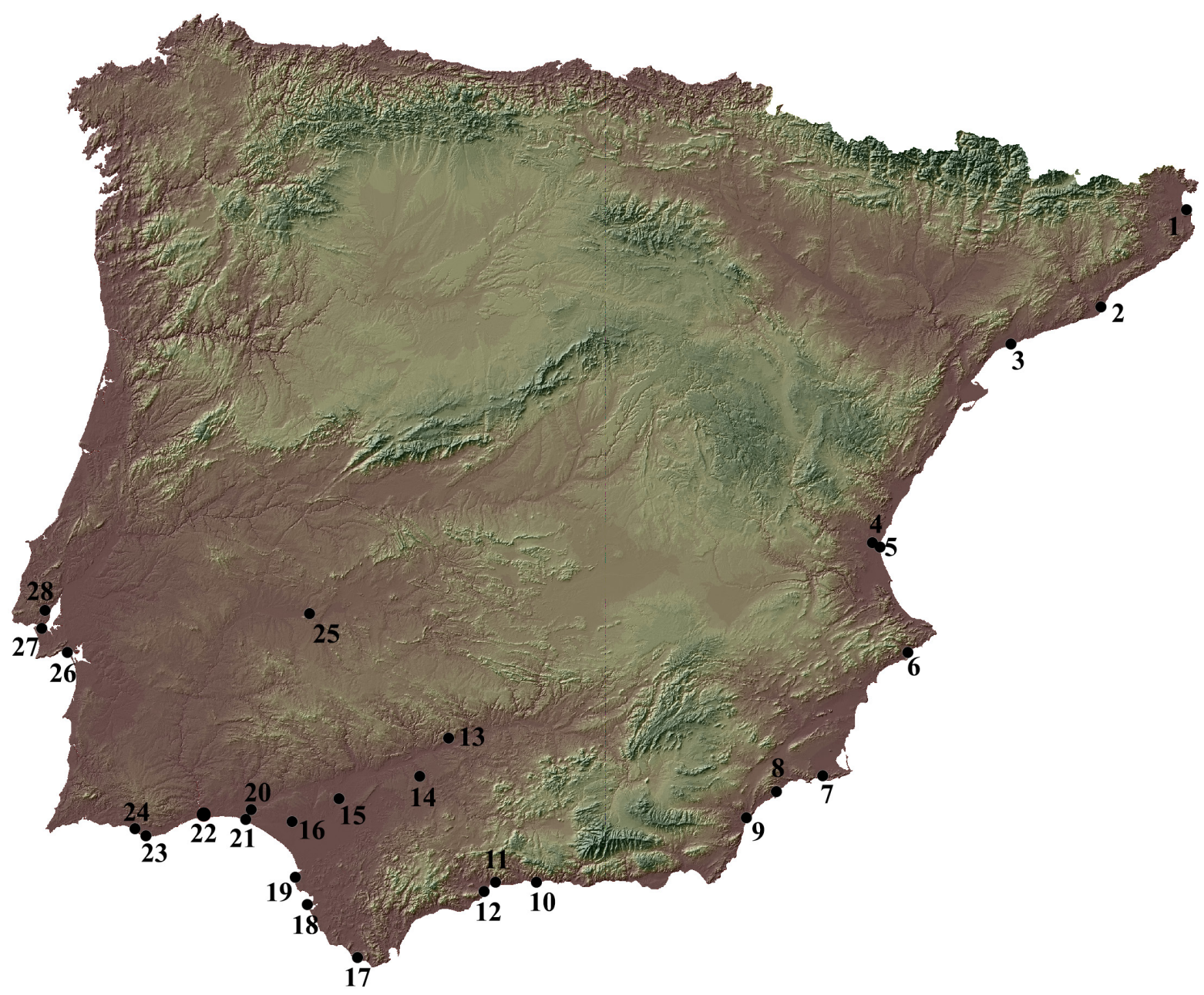

1-Ampúrias; 2- Barcelona; 3- Tarragona; 4- L’Almoina, Valência; 5-Valência; 6- Alicante; 7- Cartagena; 8- Águilas; 9- Almeria; 10- Torrox; 11- Málaga; 12- Torremolinos; 13- Córdoba; 14- Écija; 15- Sevilha; 16- Cerro del Trigo; 17- Tarifa; 18-Cádis; 19- Chipiona; 20- Huelva; 21- El Eucaliptal; 22- Ayamonte, Punta del Moral; 23- Faro- necrópole de Ossonoba e necrópole de São Cristóvão; 24- Cerro da Vila; 25- Mérida; 26- Tróia, Setúbal; 27- Almada; 28- Loures, Vila das Almoinhas.

Figura 5. Dispersão dos contextos de enterramentos infantis em ânfora na Península Ibérica (Séculos IV a V/VI d.C.). Mapa de base Global Multi-Resolution Topography (alterado).

Ainda em Tarragona foram identificados outros quatro enterramentos infantis em ânfora na intervenção que decorreu na carrer de Sant Auguri (Ciurana 2011: 274), associados a contextos datados de meados do século IV d.C. e a um mausoléu absidal (Adserias et al. 2000: fig. 3).

Também na área alicantina foram praticados estes enterramentos. Porém, se até aqui vimos descrevendo casos de necrópoles urbanas, em Alicante os dois contextos conhecidos foram registados nas villae de L 'Albir e Casa Ferrer I. Aquela tem a particularidade de ter um sector funerário dedicado exclusivamente a infantes e neonatos, datado do século IV e primeira metade do $\mathrm{V}$ d.C., onde foi documentado um enterramento em ânfora (Frías 2012). Da villa romana de Casa Ferrer I sabemos apenas que este rito também foi praticado durante o século V d.C. (Gómez Bellard e Miguel Ibáñez 1997), sem que saibamos mais pormenores sobre o tipo de ânfora e a idade dos inumados.

Convém ainda destacar a existência de alguns casos, sobretudo em Barcelona (Beltrán de Heredia Bercero 2010: 371 e 380) e em Valência (Alapont y Ribera 2006: 165-168), que foram datados dos séculos V e VI d.C., ainda que as ânforas classificadas apresentem formas análogas às que citámos. Ainda assim, salientamos 
o caso da villa romana de Sant Pau del Camp, em Barcelona, onde se identificou um enterramento infantil realizado em ânfora de tipo Keay LXIA (Beltrán de Heredia Bercero 2010: 380), que data dos séculos VI-VII d.C. Notamos, portanto, uma permanência deste rito inumatório na costa catalã e levantina.

Na comunidade de Múrcia conhecemos um único caso, em Águilas, de um neonato inumado numa ânfora de tipo Keay XIX (Hernández García 1998: 181). Trata-se de uma necrópole de uma cidade litoral que, segundo o autor, transparece uma considerável reactivação económica a partir de final do século III d.C., situação que é também constatada nos contextos funerários (ibidem: 203).

Em Cartagena este tipo de enterramento está identificado na necrópole de San Antón (Berrocal y Laiz 1995: 174). Infelizmente, os autores não optaram por uma descrição mais extensa deste rito, ficando por esclarecer o número de casos identificados, as idades e se algum destes correspondia a inumações de adultos, pois é referida a utilização de mais que uma ânfora no mesmo enterramento. Segundo a análise tipológica das ânforas (Keay III, IV, XXV, LXII e Almagro 51), foi avançada uma datação balizada na segunda metade do século IV d.C. para estes enterramentos (Laiz y Berrocal 1995: 170-171).

Em Málaga, destacam-se as necrópoles de Torremolinos e Torrox. Na primeira foram reconhecidos cinco enterramentos efectuados em ânforas do tipo Keay VII (Africana II), todos infantes, constituindo, dada a ausência de espólio, os únicos recipientes que permitiram datar os enterramentos dos séculos IV-V d.C. (Serrano et al. 1993: 210), situação, aliás, bastante comum nas necrópoles deste período. Na necrópole de Torrox (Serrano 2006: 160; Infantas y Puerto 2010: 3496), por sua vez, a ânfora utilizada foi a de tipo Keay XIX (Almagro 51) oferecendo datações idênticas.

A partir do século III d.C. também em Baelo Claudia se documentam enterramentos infantis em ânfora. Não obstante, seria espectável que os espaços funerários da cidade baelonense oferecessem esta tipologia de enterramentos em maior quantidade que a que vem sendo constatada. De facto, desde os trabalhos de Bonsor não se haviam documentado outros enterramentos infantis em ânfora (Muñoz et al. 2009: 48, fig. 69). Somente nas recentes escavações efectuadas pela Universidade de Alicante (campanha de 2014) se incrementou o número deste tipo de enterramentos (Prados y Jiménez 2016), ainda assim, um único caso foi identificado, na necrópole oriental, no qual foi utilizada uma ânfora de tipo Puerto Real 2.
$\mathrm{Na}$ intervenção da Avenida de Portugal (Cádiz) identificou-se um único enterramento em ânfora de tipo Keay XVI, que permitiu datá-lo do século IV d.C. (Bueno y Blanco 2010: 309). Porém, ainda na área gaditana, a identificação da necrópole de Chipiona ofereceu um contexto excepcional que tem vindo a ser alvo de distintas interpretações: de um total de 22 enterramentos, 19 indivíduos foram sepultados no interior de ânforas (quadro 1 e fig. 7), sendo a necrópole exclusivamente infantil. De facto, um estudo antropológico preliminar evidenciou que a maioria dos indivíduos não ultrapassou os três meses de vida, situação que corrobora que este espaço recebeu maioritariamente nados-mortos e neonatos falecidos prematuramente, sem que aparentem vestígios de morte violenta (Alcázar et al. 1994). Apesar da excepcionalidade do achado, é arriscado afirmar que esta necrópole evidencia uma mortalidade infantil elevada, pois estes dados deveriam ser comparados com os da necrópole coeva que recebeu adultos. Por outro lado, tendo em conta a limitada área intervencionada, não é improvável que nas proximidades possa estar a necrópole comum, sendo aquela um sector concreto que a complementa.

As ânforas documentadas neste contexto correspondem aos tipos Keay XXIII (Almagro 51C), XVI, XXV, LVI e Africana II (Alarcón 1993; Lagóstena 2001: 116), formas que permitiram uma datação desse espaço balizado entre meados do século III d.C. e meados da centúria seguinte (Alcázar et al. 1994: 38). Ainda que em alguns, poucos, casos os enterramentos tenham sido efectuados com duas metades, superiores ou inferiores, de diferentes ânforas, os mais comuns são os que apresentam um único contentor quebrado na base do colo para a inserção do cadáver (fig. 7).

Este achado motivou um interessante debate sobre as razões que levaram à existência deste espaço funerário. Uma dessas interpretações valorizou o curto espaço temporal em que se efectivaram estes sepultamentos e a restringida faixa etária dos inumados (1,8-3,5 meses) para defender a existência de mortes devidas a epidemias ou infanticídio (Alcázar et al. 1994).

Embora não tenhamos dados que permitam descartar de todo estas possibilidades, temos, contudo, alguns indícios que as contrariam. No primeiro caso, reconhecemos que uma epidemia colhia, habitualmente, os indivíduos de mais tenra idade. No entanto, sendo este o caso, seria expectável que a idade dos inumados fosse mais variada e os elementos datantes mais congruentes, uma vez que a sua formação deveria ser efectuada num marco temporal ainda mais restrito. 

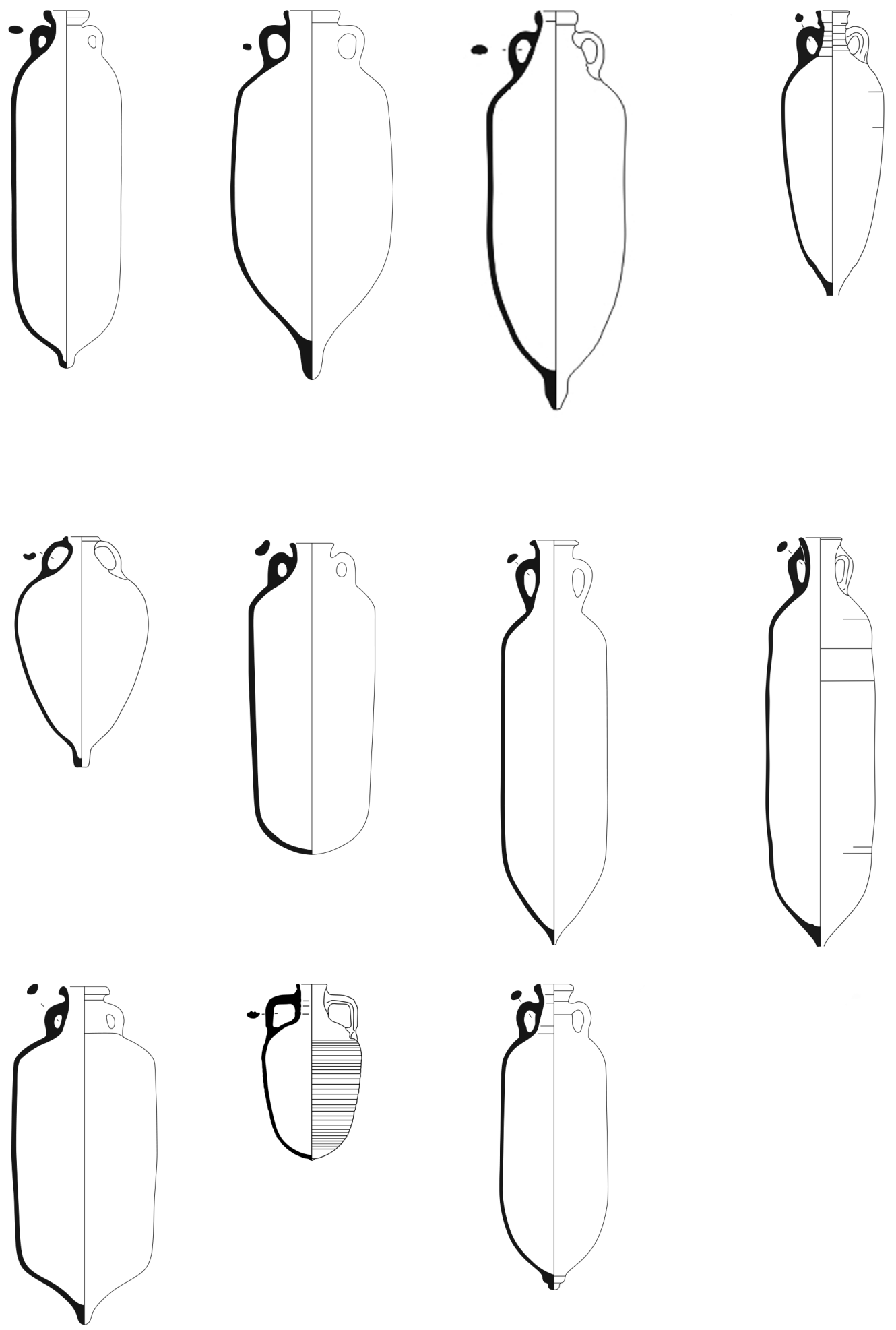

Figura 6. Tipologia de ânforas identificadas no Parc de la Ciutat, Tarragona (Dupré i Raventós et al. 1987: 114, fig. 92). 


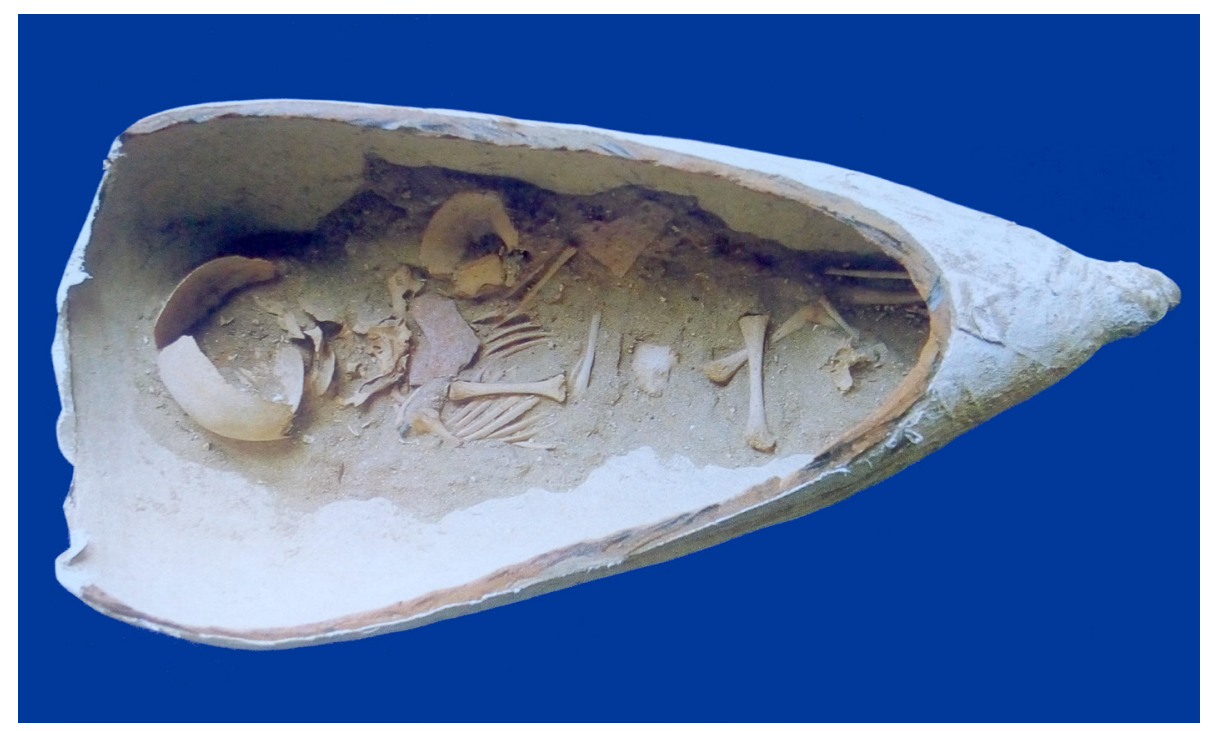

Figura 7. Enterramento $\mathrm{n}^{\circ} 11$ da necrópole de Chipiona, Cádis, contendo um feto (Alcázar et al. 1994: 45).

Por outro lado, associar este contexto a rituais sacrificiais, ou de idêntica natureza, parece demasiado arriscado, pois nenhuma análise antropológica revelou a existência de mortes violentas. Ainda assim, alguns autores afirmam que a prática de infanticídio na Antiguidade foi uma realidade comum, por asfixia ou afogamento, que pretendia controlar a dimensão das famílias (Langer 1974). Efectivamente, a sobrevivência de um recém-nascido dependia do seu reconhecimento por parte do pater familias, o qual detinha o poder de destino dos membros da família. Contudo, os inumados da necrópole de Chipiona saem, como os próprios autores reconheceram (Alcázar et al. 1994: 46-47), dessa faixa etária.

Não é fácil determinar os motivos que fomentaram a formação deste espaço funerário, nem a causa da morte dos inumados. Porém, é evidente uma eleição restringida a indivíduos falecidos prematuramente ou nados-mortos. Somos de opinião que, apesar da raridade do achado, a existência de áreas funerárias destinadas exclusivamente a crianças era uma realidade frequente durante os séculos IV e V d.C., quer se trate de sectores das necrópoles ou de áreas independentes. A sua leitura e interpretação dependem, na maioria dos casos, de uma análise comparativa com outras áreas ou sectores funerários contemporâneos.

Esta situação é particularmente visível em El Eucaliptal (Huelva) que, embora não corresponda a uma necrópole exclusivamente infantil, apresenta um sector dedicado apenas a nados-mortos, neonatos e crianças falecidas prematuramente. Além desta diferença em relação à necrópole gaditana, também a faixa etária parece ser mais diversificada, embora não exceda os 13 meses de vida (Campos et al. 1999). Identificaram-se 26 enterramentos em ânforas de tipos Keay XXIII (Almagro 51C), XVI-XXII (Almagro 50) e XXV, que, juntamente com o espólio identificado no seu interior, permitiram datar a fase II da necrópole nos séculos IV e V d.C. (ibidem: 228). Trata-se, portanto, de um espaço funerário preexistente, mas que, a partir de determinado momento, passou a integrar apenas crianças.

Além deste contexto, também no Cerro del Trigo apareceram três sepulturas infantis em ânfora (neonatos) (Bonsor 1928: 14-16), das quais desconhecemos o tipo de ânfora utilizadas, e três em Punta del Moral, em Ayamonte (López et al. 2006: 239). Ambos contextos foram datados do século IV d.C., datação extensível aos que foram detectados na necrópole Norte de Onoba. Aí foram documentados dois enterramentos infantis em ânfora, em distintas intervenções (Amo y de la Hera 1976; Vidal y Campos 2006: 16-17), realizados em contentores da forma Almagro 50.

No litoral Algarvio, embora este rito não esteja abundantemente identificado, está comprovado pela existência de seis casos nas necrópoles de Faro: quatro da necrópole suburbana da Horta de São Cristóvão (Pereira 2014a: 320) (fig. 8) e dois da necrópole do Largo 25 de Abril (Teichner et al. 2007: 175-176; Pereira 2014a: 292). A estes devemos somar ainda outros identificados nos contextos funerários da villa romana do Cerro da Vila (Matos 1985; Pereira 2014a: 415), em Vilamoura, mas que permanecem inéditos desde a década de 80 . As ânforas empregues para as inumações realizadas nestas necrópoles pertencem às 
formas Almagro 51C, Keay XXVB e LXXVIII, situação que ofereceu datações do século IV e primeira metade do $\mathrm{V}$ d.C.

Já na costa ocidental portuguesa, encontramos uma considerável quantidade (27 casos) de enterramentos infantis em Tróia (Setúbal), situação que J. Almeida relacionou com uma forte presença de populações africanas (2009: 93 e 113-114). Os enterramentos, integralmente infantis, foram realizados em ânforas das formas Almagro 50, 51 A-B, 51C, Africana IID, mas sobretudo em ânforas de tipo Keay LXXVIII. Ainda que se tenha registrado produções béticas e africanas nesses contextos funerários, os enterramentos infantis, datados da segunda metade do século III d.C. e início do seguinte, parecem ter sido introduzidos apenas em ânforas de produção sadina. Estas produções, embora obriguem a ponderar uma eventual utilização ex novo dos contentores anfóricos, não inviabilizam a reutilização daqueles que foram importados.

No ager olisiponensis encontrámos apenas um caso na vila romana das Almoinhas (Brazuna e Coelho 2012: 107) e outro, já na margem esquerda do Tejo, na Quinta da Torrinha, em Almada (Assis y Barbosa 2008; Barbosa y Aldana 2006), datado dos séculos IV-V d.C. O primeiro caso é bastante inédito quanto ao contexto em que aparece. A ânfora, contendo uma inumação de um infante, foi registada no interior de uma lixeira sem aparente interface para a sua colocação (Coelho 2008: 172173). Supõe-se, portanto, que o inumado, apesar de ter direito a um féretro, foi abandonado à superfície.

Não é improvável que, no território actualmente português, existam mais casos de enterramentos infantis em ânfora, sobretudo na área meridional. No entanto, e como afirmámos, a pouca atenção que vem sendo dada a este rito em concreto fomenta um considerável desconhecimento de contextos onde este foi praticado.

Conquanto até aqui tenhamos exposto apenas os casos imediatamente litorais, na Península Ibérica também conhecemos outros, mais interiores, que comprovam que este rito se expandiu para cidades interiores próximas a áreas de evidente produção anfórica e com um fácil acesso ao litoral, como Sevilha (Barragán 2006: 128-129; Carrasco y Doreste 2005) ou Córdoba (Santos 1955; Ruiz 2009: 157), embora percentualmente em menor quantidade (um enterramento em Sevilha e dois em Córdoba). Mais surpreendente é a existência de dois enterramentos em ânfora em Mérida, documentados na intervenção de Marquesa de Pinares (Sánchez 2001: 63-64), datados entre meados do século III e início do V d.C.

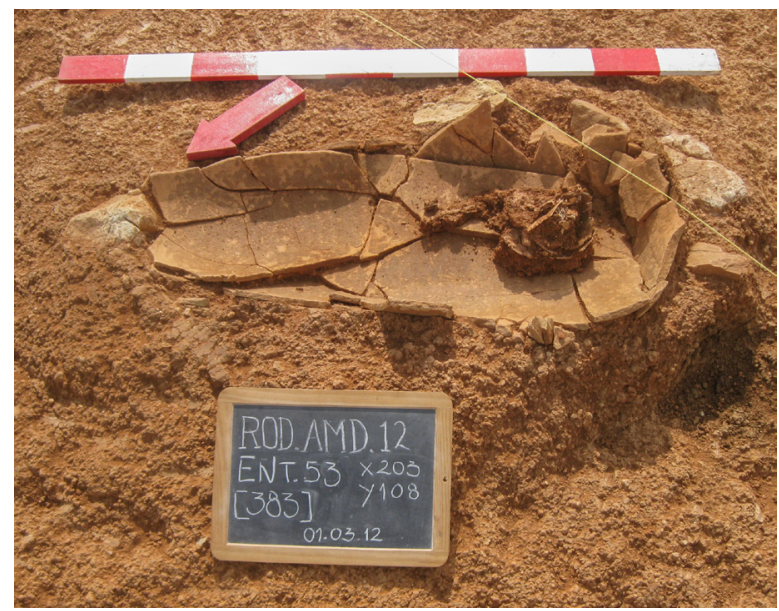

Figura 8. Enterramento $n^{\circ} 53$ da necrópole de São Cristóvão, Faro (Pereira 2014: vol. II, Estampa 70.2). Fotografia de Miguel Barbosa.

\section{EM SUMA}

A elevada mortalidade infantil na Antiguidade pode ser, como vimos ao longo deste trabalho, explicada a partir de múltiplos factores, tanto naturais como resultantes da própria intervenção humana. Preferimos, no entanto, valorizar as manifestações funerárias que reflectem alguns aspectos sociais relevantes, nomeadamente o status dos progenitores, a (des)valorização das crianças perante a lei e a sociedade, bem como as várias etapas pelas quais um indivíduo passa desde o seu nascimento. Isto pode justificar, por exemplo, o caso de Ashkelon (Israel), onde se detectou uma elevada presença de neonatos, atirados para os esgotos de um edifício termal, que, segundo alguns autores, pode ser o resultado da proximidade de um lupanar ou, inclusive, da utilização das termas, durante o Alto-Império, para tal propósito (Smith e Kahila 1992).

Outros casos apontam para o infanticídio ou exposição infantil (ius exponendi: cf. Grubbs 2013), que por sua vez podem ser reflexo de exclusão do neonato por parte do pater familias pelos mais variados motivos (filho ilegítimo, nascido após um divórcio ou fora do casamento, morte do pai, deficiência, etc.). A isto juntar-se-ia o desenvolvimento de mecanismos de controlo demográfico (contracepção, aborto: Prioreschi 1995; González Gutiérrez 2015).

Todos estes aspectos merecem um estudo que permita individualizar cada um dos casos assinalados e explicar os enterramentos registados, o que excederia os propósitos deste trabalho. No entanto, foi possível constatar nesta abordagem geral que o tratamento de 
uma criança falecida antes de cumprir um ano não foi o mesmo de neonatos que foram expostos e abandonados. Há que considerar, por outro lado, a parcialidade do registo arqueológico e os vários problemas inerentes às publicações dos resultados das escavações.

Outro tanto deve ser dito dos sistemas simbólicos que justificaram o uso das ânforas em enterramentos desta natureza, nomeadamente a relação entre o contentor e o útero. A esmagadora maioria destes enterramentos é de indivíduos com idades compreendidas entre $2 / 3$ meses e 1 ano, mas registou-se também uma paulatina presença de deposições de indivíduos que superam essa idade. Conquanto não possamos confirmar ou refutar esta relação, é um facto que esta situação permite questionar tal simbolismo.

A análise dos dados justificou a definição de dois momentos distintos, $s c$., antes e depois da segunda metade do século III d.C. (quadros 2 e 3, respectivamente), que apresentam algumas semelhanças e diferenças que podem ser comentadas.

No primeiro, a predominância de idades entre os $2 / 3$ e 12 meses pode ser resultado de os infantes serem considerados seres puros e frágeis que pereceram demasiado cedo. Já haviam passado os 40 dias posteriores ao nascimento, mas também não haviam alcançado a idade suficiente para que pudessem ser cremados. Assim, entre as práticas de enterramentos eleitas encontramos frequentemente a utilização das ânforas. Nesse momento não é frequente a utilização deste contentor para o enterramento de crianças de idade superior a um ano, situação que pode resultar da maior dimensão do inumado ou idade suficiente para a prática da cremação. Contrariamente, no segundo momento notámos um incremento de casos que superam a idade, à morte, de um ano, o que pode resultar da generalização da prática da inumação, conhecendo-se, inclusive, casos de adultos que receberam as mesmas exéquias.

Noutros aspectos, assinalam-se algumas diferenças relevantes, concretamente o número de casos identificados que está directamente relacionado com questões cronológicas e geográficas. No primeiro momento, os enterramentos conhecidos $(c \text { de } 20)^{1}$ circunscrevem-se a Barcelona, a Valência, a Málaga, a Cádis, a Écija e a Córdoba (quadro 2); do segundo conhecem-se cerca de 440 casos, distribuídos por uma área mais alargada, que chega a atingir o litoral português (áreas de Faro e Lisboa) e as Baleares (quadro 3), fazendo sobressair o incremento substancial deste ritual na costa mediterrânica

1. As publicações nem sempre fornecem informações precisas sobre a quantidade de enterramentos. e atlântica (figs. 6 e 7). Reparámos ainda que, independentemente do âmbito cronológico, este rito concentra-se, principalmente, em áreas litorais.

A variedade tipológica das ânforas (quadros 2 e 3) revela que não há uma relação específica entre a forma e a finalidade que os recipientes acabaram por ter. $\mathrm{O}$ mesmo pode ser dito se considerarmos o seu conteúdo primário (quando este foi analisado), uma vez que estas ânforas foram utilizadas para o transporte de vinho, azeite e, na maioria dos casos, tanto no primeiro como no segundo momento, preparados piscícolas. Estes dados podem, portanto, dar a entender que a sua (re)utilização no funus resulta de uma pragmática utilidade do contentor como féretro, situação que é fomentada pelo fácil acesso a ânforas descartadas, ou compradas directamente na figlina, além do evidente ajuste da dimensão do recipiente ao inumado. Tal não exclui os comentários que tecemos sobre a relação entre ânfora e útero. Não parece, como tal, descabido afirmar que a (re)utilização destes contentores nos enterramentos está relacionado com a facilidade de aquisição em centros de produção, particularmente no litoral e em rios navegáveis como o Guadalquivir, onde a circulação destes contentores era evidentemente mais intensa.

Estamos, portanto, perante casos de evidente reutilização de contentores anfóricos de várias origens, quer local (lusitanos na área ocidental, béticos na meridional), quer externa (africanos na costa oriental), situação bem patente no segundo momento. Há, ainda assim, uma clara relação entre o uso das ânforas no funus e a proximidade dos centros produtores ou de comércio. Admitimos, contudo, que o mesmo não podemos assegurar para os contentores anfóricos produzidos na mesma região onde foram utilizados como féretro, embora as importações correspondam indubitavelmente a reutilizações.

Conquanto possamos intuir alguma responsabilidade da expansão do Cristianismo no incremento desta prática, importa ainda fazer referência a outros factores que, eventualmente, podem assumir um papel igualmente preponderante. Referimo-nos, concretamente, à crise do século III d.C., momento a partir do qual se denota uma uniformidade nos relatos de autores clássicos afirmando que se viviam tempos de claro deterioro das condições de vida (Chic 2005). Reparamos, assim, num certo sincronismo entre este momento e o incremento da utilização das ânforas enquanto contentor fúnebre, que pode ser facilmente justificado por uma cada vez mais evidente incapacidade aquisitiva.

Todavia, já foi alertado que estes epifenómenos não podem ser justificados apenas por um factor (Pereira 
Quadro 2. Lista de sítios com inumações infantis em ânforas (século I a III d.C.).

\begin{tabular}{|c|c|c|c|c|c|}
\hline Sítio & Referência & $\begin{array}{l}\text { Forma da } \\
\text { ânfora }\end{array}$ & $\begin{array}{l}\text { Cronologia } \\
\text { atribuída ao } \\
\text { enterramento }\end{array}$ & $\mathrm{N}^{\mathrm{o}}$ de casos & $\begin{array}{l}\text { Idade à } \\
\text { morte }\end{array}$ \\
\hline $\begin{array}{l}\text { Villajoyosa, } \\
\text { Alicante }\end{array}$ & $\begin{array}{c}\text { http://terraeantiqvae.com/group/hispania- } \\
\text { prerromana/forum/topics/salen-a-la-luz- } \\
\text { en-villajoyosa-alicante-150-tumbas-de- } \\
\text { varios-siglo?overrideMobileRedirect=1\#. } \\
\text { VrhcVjYrEu4 }\end{array}$ & $? ? ?$ & $\begin{array}{l}\text { Século I-II } \\
\text { d.C. }\end{array}$ & 1 & $\begin{array}{c}\text { Cerca de } 9 \\
\text { meses }\end{array}$ \\
\hline Denia, Alicante & Gisbert Santonja e Senti Ribes 1989 & $\begin{array}{l}\text { Dressel 2/4 } \\
\text { tarraconense }\end{array}$ & $\begin{array}{l}\text { Século I-II } \\
\text { d.C. }\end{array}$ & $\begin{array}{l}4 \text { no interior } \\
\text { de edifício } \\
\text { (horreum) }\end{array}$ & $\begin{array}{l}\text { Fetos/ } \\
\text { nados- } \\
\text { mortos }\end{array}$ \\
\hline $\begin{array}{l}\text { Calle Avellano, } \\
\text { Córdoba }\end{array}$ & Penco Valenzuela 1998 & Beltrán IIB & $\begin{array}{l}1^{\mathrm{a}} \text { metade do } \\
\text { I d.C. }\end{array}$ & 1 & Infante \\
\hline $\begin{array}{c}\text { Calle Beatriz } \\
\text { Enríquez, Córdoba }\end{array}$ & $\begin{array}{l}\text { Moreno Romero 2006: 238; } \\
\text { Ruiz Osuna 2009: 62-63 }\end{array}$ & $\begin{array}{c}\text { Dressel 7-11 e } \\
\text { Haltern } 70\end{array}$ & Século I d.C. & $\begin{array}{l}\text { Área Pró- } \\
\text { pria }\end{array}$ & $\begin{array}{c}\text { Infantes e } \\
\text { neonatos }\end{array}$ \\
\hline $\begin{array}{l}\text { Paseo de los Tilos, } \\
\text { Málaga }\end{array}$ & Vaquerizo Gil 2007: 394 & Beltrán VI & $\begin{array}{l}\text { Século II-III } \\
\text { d.C. }\end{array}$ & 1 & Infante \\
\hline $\begin{array}{c}\text { Barrio de la } \\
\text { Trinidad, Málaga }\end{array}$ & Melero García 2009: 2438 & Beltrán IV & $\begin{array}{l}\text { Século I-III } \\
\text { d.C. }\end{array}$ & 1 & Infante \\
\hline $\begin{array}{c}\text { Necrópole Ociden- } \\
\text { tal de Barcino, } \\
\text { Barcelona }\end{array}$ & Heredia Bercero 2007: 30 & $\begin{array}{l}\text { Ânfora Byza- } \\
\text { cena, tipo Afri- } \\
\text { cana "piccola" }\end{array}$ & $\begin{array}{l}\text { Século III } \\
\text { d.C. }\end{array}$ & 1 & $\begin{array}{l}\text { Criança, } \\
1,5 \text { anos }\end{array}$ \\
\hline $\begin{array}{c}\text { Necrópole Sul de } \\
\text { Onoba, Huelva }\end{array}$ & Castilla Reyes et al. 2004: 504 & $? ? ?$ & $\begin{array}{l}\text { Século I-II } \\
\text { d.C. }\end{array}$ & 1 & $? ? ?$ \\
\hline $\begin{array}{l}\text { Necrópole funda- } \\
\text { cional de Valencia } \\
\text { (calle Quart) }\end{array}$ & García Prósper et al. 2002-2003: 282 & $? ? ?$ & Século I a.C. & 1 & $? ? ?$ \\
\hline $\begin{array}{c}\text { Portal de Russafa, } \\
\text { Valencia }\end{array}$ & González Villaescusa 2001: 235 & Dressel 2-4 & Século I d.C. & 1 & $? ? ?$ \\
\hline $\begin{array}{l}\text { La Boatella, } \\
\text { Valencia }\end{array}$ & González Villaescusa 2001: 226-227 & $\begin{array}{c}\text { Lamboglia 2, } \\
\text { Dressel 2-4, } \\
\text { Almagro 51c e } \\
\text { Keay XXIII }\end{array}$ & $\begin{array}{l}\text { Século I a.C. } \\
\text { a IV d.C. }\end{array}$ & $? ? ?$ & $? ? ?$ \\
\hline $\begin{array}{c}\text { Solar de la Futura, } \\
\text { Cádis }\end{array}$ & Sibón et al. 2007: 151 & $\begin{array}{c}\text { Dressel } 20 \\
7 / 11 \text { e } 12\end{array}$ & Século I d.C. & 2 & $? ? ?$ \\
\hline $\begin{array}{c}\text { Calle García } \\
\text { Carrera 9, Cádis }\end{array}$ & Córdoba Alonso e Belizó 2010: 437 & Dressel 7/11 & $\begin{array}{l}\text { Século I a.C.- } \\
\text { I d.C. }\end{array}$ & 1 & ??? \\
\hline $\begin{array}{c}\text { Baelo Claudia, } \\
\text { Tarifa }\end{array}$ & Bendala Galan 1992; & ??? & Século I d.C. & $1 ? ?$ & ??? \\
\hline $\begin{array}{l}\text { Necrópole Ociden- } \\
\text { tal de Astigi, Écija }\end{array}$ & $\begin{array}{l}\text { Ruiz Osuna 2006; Aguilar Camacho 2004: } \\
\text { 895; Tinoco Muñoz } 2004\end{array}$ & $\begin{array}{l}\text { Dressel 20/ } \\
\text { Beltran IIB }\end{array}$ & Século I d.C. & 3 & $\begin{array}{c}2 \text { Infantes? } \\
1 \text { incine- } \\
\text { ração }\end{array}$ \\
\hline
\end{tabular}


Quadro 3. Lista de sítios com inumações infantis em ânforas (século III a V/VI d.C.).

\begin{tabular}{|c|c|c|c|c|c|}
\hline Sítio & Forma da ânfora & $\begin{array}{l}\text { Cronologia atribuída } \\
\text { ao enterramento }\end{array}$ & $\mathrm{N}^{\mathrm{o}}$ de casos & $\begin{array}{c}\text { Idade à } \\
\text { morte }\end{array}$ & Referência \\
\hline Cerro da Vila, Algarve & $? ? ?$ & $? ? ?$ & $? ? ?$ & $? ? ?$ & Matos 1985 \\
\hline $\begin{array}{l}\text { Necrópole da Horta de } \\
\text { São Cristóvão, Faro }\end{array}$ & $\begin{array}{c}\text { Almagro 51C Keay } \\
\text { LXXVIII }\end{array}$ & Século IV d.C. & 4 & $? ? ?$ & Pereira 2014: 320 \\
\hline Largo 25 de Abril, Faro & Keay XXVB & Século IV-V d.C. & 2 & $? ? ?$ & $\begin{array}{c}\text { Teichner et al. 2007: } \\
\text { 175-176; Pereira 2014: } \\
292\end{array}$ \\
\hline $\begin{array}{l}\text { Vila das Almoinhas, } \\
\text { Loures }\end{array}$ & $? ? ?$ & $? ? ?$ & 1 & $? ? ?$ & $\begin{array}{c}\text { Brazuna e Coelho } \\
\text { 2012: } 107\end{array}$ \\
\hline $\begin{array}{l}\text { Necrópole da Caldeira, } \\
\text { Tróia, Setúbal }\end{array}$ & $\begin{array}{l}\text { Almagro 50, 51C, } 51 \\
\text { a/b, Keay LXXVIII e } \\
\text { Africana IID }\end{array}$ & Século III-IV d.C. & 27 & $? ? ?$ & Almeida 2009: 93 \\
\hline $\begin{array}{c}\text { Quinta da Torrinha / } \\
\text { Quinta de Santo } \\
\text { António, Almada }\end{array}$ & $? ? ?$ & Século IV-V d.C. & 1 & $? ? ?$ & $\begin{array}{l}\text { Assis e Barbosa 2008; } \\
\text { Barbosa e Aldana } 2006\end{array}$ \\
\hline $\begin{array}{c}\text { Marqueza de Pinares, } \\
\text { Mérida }\end{array}$ & $? ? ?$ & Século III-V d.C. & 2 & Neonatos & $\begin{array}{c}\text { Sánchez Sánchez 2001: } \\
63-64\end{array}$ \\
\hline Les Vinyals, Alicante & $\begin{array}{l}\text { Almagro 50/Keay XXII } \\
\text { e Almagro 51/Keay XIX }\end{array}$ & Século IV-V d.C. & 2 & $? ? ?$ & $\begin{array}{l}\text { González Villaescusa } \\
\text { 2001: } 355 \text { e ss. }\end{array}$ \\
\hline $\begin{array}{l}\text { Vila romana de l'Albir, } \\
\text { Alicante }\end{array}$ & Almagro 51c & Século IV-V d.C. & $\begin{array}{c}1 \text { em área } \\
\text { própria para } \\
\text { infantes }\end{array}$ & $? ? ?$ & Frías Castillejo 2012 \\
\hline $\begin{array}{l}\text { Vila romana Casa } \\
\text { Ferrer I, Alicante }\end{array}$ & $? ? ?$ & Século IV d.C. (final) & $? ? ?$ & $\begin{array}{l}\text { Fetos/Na- } \\
\text { dos-mor- } \\
\quad \text { tos }\end{array}$ & $\begin{array}{l}\text { Gómez Bellard e Mi- } \\
\text { guel } 1997\end{array}$ \\
\hline $\begin{array}{c}\text { Parc de la Ciutat, } \\
\text { Tarragona }\end{array}$ & Keay XIX & Séculos IV-V d.C. & $\begin{array}{c}38 \\
\text { (9 infantis) }\end{array}$ & $\begin{array}{l}9 \text { Infantes } \\
\text { e } 29 \text { adul- } \\
\text { tos }\end{array}$ & $\begin{array}{c}\text { Dupré i Raventós et } \\
\text { al., } 1987\end{array}$ \\
\hline $\begin{array}{l}\text { Prat de la Riba, } \\
\text { Tarragona }\end{array}$ & $\begin{array}{l}\text { Keay IIIB, IV, VI, XXV, } \\
\text { XXVII, Almagro 51A-B, } \\
\text { Almagro 51C, }\end{array}$ & Séculos IV-V d.C. & 196 & $\begin{array}{l}\text { Infantes e } \\
\text { adultos }\end{array}$ & $\begin{array}{l}\text { Foguet e Vilaseca } \\
\text { 1995: 158; Remolá e } \\
\text { Vilaseca 2000: } 79\end{array}$ \\
\hline $\begin{array}{c}\text { Peri } 2 \text { (Calle Jaume I, } \\
\text { Tarragona }\end{array}$ & $\begin{array}{l}\text { Africana II, Keay XX- } \\
\text { VIIB e Emporitana }\end{array}$ & Séculos IV-V d.C. & 3 & $\begin{array}{l}\text { Neonato e } \\
\text { infantes }\end{array}$ & $\begin{array}{l}\text { García Noguera e Re- } \\
\text { molà Vallverdú } 2000\end{array}$ \\
\hline $\begin{array}{c}\text { Jardín de la Catedral, } \\
\text { Tarragona }\end{array}$ & $? ? ?$ & $? ? ?$ & 1 & Infante & $\begin{array}{l}\text { Hauschild 1994: 153; } \\
\text { Sanchéz Ramos 2006; } \\
\text { Gurt Esparraguera e } \\
\text { Macias i Solé 2002: } 96\end{array}$ \\
\hline San Antón, Cartagena & $\begin{array}{l}\text { Keay III, IV, XXV, LXII } \\
\text { e Almagro } 51\end{array}$ & Séculos IV-V d.C. & $? ? ?$ & $? ? ?$ & $\begin{array}{l}\text { Berrocal Caparrós e } \\
\text { Laiz Reverte } 1995\end{array}$ \\
\hline $\begin{array}{l}\text { Calle Gloria - calle Jove- } \\
\text { llanos, Aguilas, Múrcia }\end{array}$ & Keay XIX & Séculos IV-V d.C. & 1 & Neonato & $\begin{array}{c}\text { Hernández García } \\
1998\end{array}$ \\
\hline $\begin{array}{l}\text { Camino Viejo de } \\
\text { Almodóvar, Córdoba }\end{array}$ & $? ? ?$ & $? ? ?$ & 2 & $? ? ?$ & $\begin{array}{c}\text { Santos Géner 1955; } \\
\text { Ruiz Osuna 2009: } 157\end{array}$ \\
\hline
\end{tabular}




\begin{tabular}{|c|c|c|c|c|c|}
\hline Sítio & Forma da ânfora & $\begin{array}{l}\text { Cronologia atribuída } \\
\text { ao enterramento }\end{array}$ & $\mathrm{N}^{\mathrm{o}}$ de casos & $\begin{array}{l}\text { Idade à } \\
\text { morte }\end{array}$ & Referência \\
\hline Torremolinos, Málaga & Keay VII & Século V d.C. & 5 & Infantes? & $\begin{array}{c}\text { Serrano Ramos et al. } \\
\text { 1993: } 210\end{array}$ \\
\hline Torrox, Málaga & Keay XIX & Século IV-V d.C. & $? ? ?$ & Infantes? & $\begin{array}{l}\text { Serrano Ramos 2006: } \\
\text { 160; Infantas Beato, } \\
\text { G. e Puerto Fernández } \\
\text { 2010: } 3496\end{array}$ \\
\hline $\begin{array}{l}\text { Necrópole de Santa } \\
\text { María del Mar, Bar- } \\
\text { celona }\end{array}$ & $? ? ?$ & Século IV-VI d.C. & $? ? ?$ & $? ? ?$ & $\begin{array}{l}\text { Balil 1956: 671; Here- } \\
\text { dia Bercero 2010: } 366 \\
\text { e ss. }\end{array}$ \\
\hline $\begin{array}{l}\text { Paseo del Born } \\
\text { (próximo de Santa Ma- } \\
\text { ría del Mar), Barcelona }\end{array}$ & Keay XXVIIB e LXII & Século V-VI d.C. & 2 & $? ? ?$ & $\begin{array}{l}\text { Heredia Bercero 2010: } \\
\qquad 371\end{array}$ \\
\hline $\begin{array}{l}\text { Santa Caterina, Bar- } \\
\text { celona }\end{array}$ & $\begin{array}{c}\text { Keay IV, XIX, XXIVA, } \\
\text { XXV }\end{array}$ & Século IV-V d.C. & 6 & $? ? ?$ & $\begin{array}{l}\text { Heredia Bercero 2010: } \\
\qquad 374\end{array}$ \\
\hline $\begin{array}{l}\text { Villa romana de Sant } \\
\text { Pau del Camp, Barce- } \\
\text { lona }\end{array}$ & Keay LXI A & Século VI-VII d.C. & 1 & $? ? ?$ & $\begin{array}{l}\text { Heredia Bercero 2010: } \\
380\end{array}$ \\
\hline $\begin{array}{l}\text { Villa Romana Antoni } \\
\text { Maura, Barcelona }\end{array}$ & $? ? ?$ & $? ? ?$ & 1 & $? ? ?$ & $\begin{array}{l}\text { Heredia Bercero 2010: } \\
\qquad 383\end{array}$ \\
\hline $\begin{array}{c}\text { Avenida Cambó, Bar- } \\
\text { celona }\end{array}$ & $\begin{array}{l}\text { formas africanas Keay } \\
\text { IIIB, IV, V, } 25,27,27 \mathrm{~b} \text {, } \\
\text { IX o X, } 41 \text {, y ánforas bé- } \\
\text { ticas, Keay XIX y orien- } \\
\text { tal tipo Keay } 54 \text { bis o } \\
\text { Late Roman Amphora } 3\end{array}$ & Século IV-V d.C. & 30 & $? ? ?$ & $\begin{array}{l}\text { Heredia Bercero 2010: } \\
\qquad 385\end{array}$ \\
\hline $\begin{array}{l}\text { Necrópole Norte de } \\
\text { Onoba, Huelva }\end{array}$ & Almagro 50 & Séculos IV-V d.C. & 1 & Neonato & $\begin{array}{c}\text { Amo y de la Hera 1976; } \\
\text { Vidal Teruel e Campos } \\
\text { Carrasco 2006: } 16\end{array}$ \\
\hline $\begin{array}{l}\text { Necrópole de la Or- } \\
\text { dem, Huelva (mesma } \\
\text { que a Norte) }\end{array}$ & $? ? ?$ & Século IV d.C. & 1 & $? ? ?$ & $\begin{array}{c}\text { Amo y de la Hera 1976; } \\
\text { Vidal Teruel e Campos } \\
\text { Carrasco 2006: } 17\end{array}$ \\
\hline $\begin{array}{c}\text { Cerro del Trigo, } \\
\text { Huelva }\end{array}$ & $? ? ?$ & Século IV d.C. & 3 & Neonatos & Bonsor 1928 \\
\hline El Eucaliptal, Huelva & $\begin{array}{c}\text { Keay XXIII, XVI-XXII } \\
\text { e XXV }\end{array}$ & Século IV-V d.C. & $\begin{array}{l}26 \text { em área } \\
\text { própria }\end{array}$ & $\begin{array}{l}\text { Fetos, } \\
\text { neonatos } \\
\text { e infan- } \\
\text { tes }\end{array}$ & $\begin{array}{c}\text { Campos Carraco et } \\
\text { al. XXX; Vidal Teruel } \\
\text { e Bermejo Meléndez } \\
2006\end{array}$ \\
\hline $\begin{array}{c}\text { Punta del Moral, Aya- } \\
\text { monte, Huelva }\end{array}$ & $? ? ?$ & Século IV d.C. & 3 & $? ? ?$ & $\begin{array}{l}\text { López Domínguez et } \\
\text { al. 2006: } 239\end{array}$ \\
\hline La Boatella, Valencia & $\begin{array}{l}\text { Lamboglia 2, Dressel } \\
\text { 2-4, Almagro 51c e Keay } \\
\text { XXIII }\end{array}$ & $\begin{array}{l}\text { Século I a.C. } \\
\text { a IV d.C. }\end{array}$ & $? ? ?$ & $? ? ?$ & $\begin{array}{c}\text { González Villaescusa } \\
\text { 2001: 226-227 }\end{array}$ \\
\hline $\begin{array}{l}\text { Plaza del Marqués de } \\
\text { Busianos, Valencia }\end{array}$ & $\begin{array}{l}\text { Keay XIX e XXIII his- } \\
\text { panicas }\end{array}$ & Século V-VI d.C. & 2 & $? ? ?$ & $\begin{array}{l}\text { Alapont Martin e Ribera } \\
\text { i Lacomba 2006: } 165\end{array}$ \\
\hline
\end{tabular}




\begin{tabular}{|c|c|c|c|c|c|}
\hline Sítio & Forma da ânfora & $\begin{array}{l}\text { Cronologia atribuída } \\
\text { ao enterramento }\end{array}$ & $\mathrm{N}^{\mathrm{o}}$ de casos & $\begin{array}{l}\text { Idade à } \\
\text { morte }\end{array}$ & Referência \\
\hline L`Almoina, Valencia & $\begin{array}{c}\text { Keay XIX e XXXVIB } \\
\text { africanas }\end{array}$ & Século V-VI d.C. & 4 & $? ? ?$ & $\begin{array}{l}\text { Alapont Martin e Ribera } \\
\text { i Lacomba, 2006: } 168\end{array}$ \\
\hline $\begin{array}{l}\text { Carretera de Carmona, } \\
\text { Sevilha }\end{array}$ & $? ? ?$ & Século V d.C. & 1 & $? ? ?$ & $\begin{array}{l}\text { Barragán Valencia } \\
\text { 2006: 128-129; Ca- } \\
\text { rrasco Gómez e Do- } \\
\text { reste Franco } 2005\end{array}$ \\
\hline Chipiona, Cádiz & $\begin{array}{c}\text { Keay XXIII, XVI, XXV } \\
\text { e LVI }\end{array}$ & Século IV a VI d.C. & 19 & $? ? ?$ & $\begin{array}{l}\text { Alarcón Castellano } \\
\text { 1993; Lagostena Ba- } \\
\text { rrios 2001: } 116\end{array}$ \\
\hline $\begin{array}{l}\text { Av. Portugal com Av. } \\
\text { Andalucia, Cádiz }\end{array}$ & Keay XVI & Século IV d.C. & 1 & $? ? ?$ & $\begin{array}{l}\text { Bueno Serrano e Blanco } \\
\text { Jiménez 2010: } 309\end{array}$ \\
\hline Baelo Claudia, Tarifa & Puerto Real 2 & Século III d.C. & 1 & $? ? ?$ & $\begin{array}{c}\text { Paris et al. } 1926 \text { : 86- } \\
\text { 87; Prados Martínez e } \\
\text { Jiménez Vialáz no prelo }\end{array}$ \\
\hline $\begin{array}{c}\text { Necrópole de } \\
\text { Villaricos, Almeria }\end{array}$ & $? ? ?$ & $? ? ?$ & $\begin{array}{l}6 \text { em área } \\
\text { concreta }\end{array}$ & $? ? ?$ & Rodero et al. 1996 \\
\hline $\begin{array}{c}\text { Necrópolis de Estruch, } \\
\text { Martí y Ballesta } \\
\text { Rubert, Ampúrias }\end{array}$ & $\begin{array}{c}\text { Keay LIV, XXV, IV, LI, } \\
\text { LIII e LV }\end{array}$ & Século V d.C. & 38 & $? ? ?$ & $\begin{array}{l}\text { Almagro Basch, 1955; } \\
\text { Agustí i Farjas et al. } \\
\text { 2000: } 48\end{array}$ \\
\hline $\begin{array}{c}\text { Necrópole de Roses, } \\
\text { Ampúrias }\end{array}$ & $\begin{array}{c}\text { Keay LXII, XXXVI B, } \\
\text { LIV, LXXXV }\end{array}$ & Século IV-V d.C. & 8 & $? ? ?$ & $\begin{array}{l}\text { Puig et al. 1998; Agustí } \\
\text { i Farjas et al. 2000: } 56\end{array}$ \\
\hline $\begin{array}{l}\text { Puig des Molins, } \\
\text { Baleares }\end{array}$ & & Século IV d.C. & 1 & $? ? ?$ & $\begin{array}{c}\text { Miguélez Ramos, } \\
\text { 1989: } 17\end{array}$ \\
\hline
\end{tabular}

2014b: 196), devendo ter-se em conta uma eventual responsabilidade partilhada entre a conjuntura que se vivia e o avanço do Cristianismo, que, como vimos, aclamava a austeridade em vida e na morte (Pereira 2015: 7). Embora isto não explique a utilização deste rito, pode justificar a sua maior visibilidade a partir da segunda metade do seculo III d.C.

Estes aspectos adquirem maior interesse quando se constata que há uma continuidade e intensificação no uso dos contentores anfóricos em plena expansão do Cristianismo. O estudo das fontes pode possibilitar uma melhor compreensão desta continuidade ou, eventualmente, o reconhecimento de uma reformulação, mas depende de uma análise mais profunda do que aquela que foi possível desenvolver nesta ocasião. Note-se, ainda, como tivemos oportunidade de salientar, que a utilização das ânforas enquanto féretro é uma prática anterior à época romana, prolongando-se até, sensivelmente, ao século VI d.C.; esta constatação levaria a ponderar os motivos que podem justificar o seu desaparecimento.
Apesar das necessárias reservas, parece haver uma relação entre o desaparecimento do ritual e a retracção da produção de ânforas, quer na Lusitânia (Fabião, 2004: 404-405), quer na Bética (García Vargas e Bernal Casasola 2008: 678-679). Paralelamente, a consolidação do Cristianismo pode ter conduzido a uma emancipação face aos rituais fúnebres anteriores, uma vez que nos primeiros momentos há uma clara continuidade no uso de espaços funerários de génese pagã e, posteriormente, um progressivo abandono desses lugares (Pereira 2014a: 336 e 444) e a criação de novos espaços.

Assim, o Cristianismo pode ter sido duplamente responsável pela expansão de um ritual de origem pagã, como tantos outros (cf. Alvar et al. 1995), criando um aparente paradoxo, mas dando-lhe outros contornos e, simultaneamente, pelo seu desaparecimento. Tal situação pode dever-se a uma possível falta de consolidação, no âmbito cristão, do tratamento do corpo, que teria levado ao uso de práticas anteriores. Esta situação foi reproduzida por várias gerações, como pudemos 
constatar, e é um ponto de partida para colocar outras questões, com as quais terminamos este trabalho.

A primeira questão diz respeito à introdução do Cristianismo na Hispânia. Alguns autores defendem que tem origem africana, partindo da Carta $67 \mathrm{de} \mathrm{Ci-}$ priano e da realização do Concílio de Elvira (Díaz y Díaz 1967: 423-443; Blázquez 1986: 93-102; Fernández Ubiña 2007). Outros, porém, apontam para uma maior diversificação de origens (García Moreno, 2005: 177).

A intensa relação comercial da Península Ibérica, sobretudo do Levante e da Catalunha, com África, aliada à importante representação do rito no Norte deste continente (Norman 2002, 2003), são argumentos que poderiam validar esta origem (Corrado 2003: 102-103). Talvez por este motivo, os núcleos urbanos litorais foram especialmente permeáveis à introdução de novas ideologias e, neste caso, à difusão de um rito que, como vimos, foi reforçado com o Cristianismo.

Apesar do que foi dito, devemos reconhecer que outros factores podem estar subjacentes à utilização destes contentores enquanto urna. Relembramos, por exemplo, a elevada diversidade de arquitecturas funerárias utilizadas em enterramentos infantis. Esta multiplicidade pode ser resultado de condições tão diversas como: estatuto da família, religião, capacidade aquisitiva ou financeira, geografia, entre outras. Apesar disso, é evidente que não podemos desligar os diferentes ritos praticados de simbolismos e, também, da própria conjuntura de cada momento.

Observando todo o panorama exposto, restam mais perguntas que respostas. No essencial, estamos perante um ritual funerário de origem claramente pagã que sobreviveu à introdução de um sistema religioso que defendia, precisamente, o fim de algumas práticas anteriores, mas que, simultaneamente, absorveu outras. Como parece óbvio, a resposta exige uma investigação mais profunda do que aquela que foi possível desenvolver nestas páginas, mas lança alguns desafios que não devem ser descartados.

Um desses desafios é a definição da origem desta difusão, especialmente no que ao território actualmente português diz respeito, tanto do rito (Corrado 2003: 102-103; cf. Almeida 2008: 113-114) como do próprio Cristianismo (Díaz y Díaz 1967: 423-443; Blázquez 1986: 93-102). Outro desafio diz respeito à relação (de regulação? de condenação?) que o Cristianismo manteve com outros aspectos, nomeadamente a exposição e o descarte de crianças, o infanticídio e a prática do aborto. Chamando novamente à colação o Concílio de Elvira, encontramos claros cânones que condenam estas atitudes, assim como os responsáveis pela morte infantil deliberada.

Estes temas podem ser desenvolvidos em estudos que contamos produzir num futuro próximo - que partem de uma comparação sistemática entre as fontes escritas e o registo arqueológico. para analisar um fenómeno que, como pudemos constatar ao longo destas linhas, tem tanto de interessante como de problemático.

\section{BIBLIOGRAFIA}

Adserias Sans, M.; Macias i Solé, J.; Ramón Sariñena, E. y Remolà Vallverdú, J. (2000): "El Mausoleo de la calle Sant Auguri de Tarragona", en V Reunió d'Arqueologia Cristiana Hispànica: 41 - 46. Cartagena (1998), Cartagena, Institut d'Estudis CatalansUniversitat de Barcelona.

Aguilar Camacho, G. (2004): "La necrópolis romana occidental de La Algodonera. Écija (Sevilla)". Anuario Arqueológico de Andalucía 2001, 2: 891-898.

Alapont Martin, L.; Ribera i Lacomba, A. (2006): “Cementerios tardoantiguos de Valencia: arqueología y antropología". Anales de Arqueología Cordobesa 17 (2): 161-194.

Alarcón Castellano, F. (1993): “Intervención arqueológica de emergencia Avda. de Sevilla $\mathrm{n}^{\circ}$ 2, Chipiona (Cadiz)". Anuario Arqueológico de Andalucía 1991: 51-57.

Alcázar Godoy, J.; Suárez López, A.; Alarcón Castellano, F. (1994): "Enterramientos infantiles en ánforas romanas". Revista de Arqueología XV (164): 36-47.

Almagro Basch, M. (1955): Las necrópolis de Ampurias: Necrópolis romanas y necrópolis indígenas. Barcelona, Seix y Barral.

Almeida, J. (2009): A necrópole romana da Caldeira, Tróia de Setúbal. Escavações de Manuel Heleno nas décadas de 40-60 do século XX. Trabajo de Fin de Master, Universidad de Lisboa, inédito.

Alvar Ezquerra, J.; Blázquez Martínez, J.; Fernández Ardanaz, S.; López Monteagudo, G.; Lozano, A.; Martínez Maza, C. y Piñero, A. (1995): Cristianismo primitivo y religiones mistéricas. Madrid, Cátedra.

Agustí i Farjas, B.; Codina, D.; Mataró Pladelasala, M.; Puig, A. (2000): "Pluralidad cultural a través del mundo funerario en los obispados de Empúries y Girona (siglos V-VIII d.C.)", en V Reunió d'Arqueologia Cristiana Hispànica: 47-62. Cartagena (1998), Cartagena, Institut d'Estudis CatalansUniversitat de Barcelona. 
Amo y de la Hera, M. del (1976): "Restos materiales de la población romana de Onuba". Huelva Arqueológica 2: 11-196.

Assis, S.; Barbosa, R. (2008): “A Necrópole Romana da Quinta da Torrinha / Quinta de Santo António, Monte da Caparica (III-V d.C.). Incursão ao universo funerário, paleodemográfico e morfométrico". Al-Madan, 2a serie, 16: 3-14.

Baills-Talbi, N.; Dasen, V. (2008): "Rites funéraires et pratiques magiques", en F.G. Jener, S. Muriel y C.R. Olaria Puyoles (coords.), Nasciturus, infans, puerulus vobis mater terra: la muerte en la infancia: 595-618. Castelló, Servei d'Investigacions Arqueològiques i Prehistòriques.

Baker, B.; Dupras, T.; Tocheri, M. (2005): Osteology of Infants And Children. 12a ed., Texas, A\&M University Press.

Barbosa, R.; Aldana, P. (2006): "Espaços e estratigrafias da Quinta de Santo António / Quinta da Torrinha (Monte da Caparica, Almada), no contexto da Pré-História recente e romanização na Península de Setúbal". Al-Madan, 2a serie, 14: 23-28.

Barragán Valencia, M. (2006): "Primeros datos sobre las necrópolis tardoantiguas de Carretera de Carmona. Hispalis". Anales de Arqueología Cordobesa 17: 119-136.

Becker, M. J. (1995): "Infanticide, child sacrifice and infant mortality rates: direct archaeological evidence as interpreted by human skeletal analysis". Old World Archaeology Newsletter 18, 2: 24-31.

Beltrán de Heredia Bercero, J. (2007): “La via sepulchralis de la Plaza Vila de Madrid. Un ejemplo del ritual funerario durante el alto imperio en la necrópolis occidental de Barcino". Quarhis 2, 3: 12-63.

Beltrán de Heredia Bercero, J. (2010): “La cristianización del suburbium de Barcino", en D. Vaquerizo Gil (ed.), Las áreas suburbanas en la ciudad histórica. Topografía, usos, función. Monografias de Arqueología Cordobesa 18: 363-396. Córdoba, Universidad de Córdoba.

Benichou-Safar, H. (1982): Les tombes puniques de Carthage: topographie, structures, inscriptions et rites funéraires. Paris, Editions du Centre National de la Recherche Scientifique.

Beilke-Voigt, I. (2008): "Burials of children in houses and settlements during the Roman Iron Age and Early Medieval period in northern Germany and Denmark", en L. Dommasnes y M. Wrigglesworth (eds.), Children, identity and the past: $16-35$. Newcastle, Cambridge Scholar Publishing.
Berger, A. (1991): Encyclopedic Dictionary of Roman Law. Philadelphia, American Philosophical Society.

Berrocal Caparrós, M.; Laiz Reverte, M. (1995): “Tipología de enterramientos en la necrópolis de San Antón en Cartagena”, en IV Reunió d Arqueologia Cristiana Hispànica: 173-182. Lisboa (1992). Barcelona, Institut d'Estudis Catalans-Universitat de Barcelona.

Blaizot, F.; Alix, G.; Ferber, E. (2003): "Le traitement funéraire des enfants décédés avant un an dans l'antiquité: études de cas". Bulletins et mémoires de la Société d'Anthropologie de Paris 15: 51-77.

Blázquez Martínez, J.M.a (1986): "La Carta 67 de Cipriano y el origen africano del Cristianismo hispano", en Homenaje a Pedro Sáinz Rodríguez, Vol. 3: 93-102. Madrid, Fundación Universitaria Española.

Bodel, J. (2000): "Dealing with the dead. Undertakers, executioners and potter's fields in ancient Rome", en V. Hope y E. Marshall (eds.), Death and disease in the ancient city: 128-151. London, Routledge.

Bonsor, J. (1928): Tartessos: excavaciones practicadas en 1923 en el Cerro del Trigo, término de Almonte (Huelva). Madrid, Junta Superior de Excavaciones y Antigüedades.

Brazuna, S.; Coelho, M. (2012): “A Villa das Almoinhas (Loures). Trabalhos arqueológicos de diagnóstico e minimização". Cira Arqueologia 1: 103-114.

Bueno Serrano, P.; Blanco Jiménez, F. (2010): "Intervención arqueológica en el solar situado en la esquina entre la Avda. de Portugal y la Avda. Andalucía (Cádiz)". Anuario Arqueólogico de Andalucía 2005: 306-314.

Campos Carrasco, J.; Pérez Macías, J.A.; Vidal Teruel, N. (1999): "El Eucaliptal, una necrópolis romana de pescadores (Punta Umbría, Huelva)". Huelva en su Historia 7: 195-231.

Carrasco Gómez, I.; Doreste Franco, D. (2005): “Continuidad de un espacio funerario en Sevilla: Excavaciones arqueológicas en el entorno de la Trinidad". Romula 4: 213-244.

Carrol, M. (2011): "Infant death and burial in Roman Italy". Journal of Roman Archaeology 24: 99-120.

Castilla Reyes, E.; Haro Ordóñez, J.; López Domínguez, M. (2003): “El solar nº 25-27 de la calle Vázquez López en la zona arqueológica de Huelva. La necrópolis sur de Onvba". Anuario Arqueológico de Andalucía 2001, I: 503-511.

Catalano, P.; Amicucci, G.; Benassi, V.; Caldarini, C.; Caprara, M.; Carboni, L.; Colonnelli, G.; DeAngelis, F.; Di Giannantonio, S.; Minozzi, S.; Pantano, W.; 
Porreca, F. (2006): “Gli insiemi funerari d'epoca imperiale: l'indagine antropologica di campo", en M. Tomei (ed.), Roma. Memorie dal Sottosuolo. Ritrovamenti archeologici 1980-2006: 560-563. Rome, Electa.

Chic García, G. (2005): "Marco Aurelio y Cómodo. El hundimiento de un sistema económico". Annaeus: anales de la tradición romanística 2: 45-66.

Ciurana i Prast, J. (2009-2011): "Mors immatura. Morir abans d'hora a Tarraco (segles I - III d.C.)". Empùries 56: 207-226.

Ciurana i Prast, J. (2011): Pràctiques i rituals funeraris a Tàrraco i el seu ager (segles II a.C.-III/IV d.C.). Tesis Doctoral, Universitat Rovira i Virgili, inédita

Coelho, M. (2008): Intervenção arqueológica de diagnóstico e minimização. Área de protecção da Villa das Almoínhas (Loures). Relatório final dos trabalhos arqueológicos. Direcção Geral do Património Cultural.

Córdoba Alonso, I.; Belizó, R. (2010): “Intervención Arqueológica Preventiva en la C/ García Carrera, 9 (Cádiz). Nuevo sector en la necrópolis romana de Cádiz". Anuario Arqueológico de Andalucía 2005: 435-438.

Corrado, M. (2003): "Le anfore tarde del "dark layer" di UC VII (US 1098)", en Siena, S.; Rossignani, M. (eds.), Dall'antichità al medioevo. Aspetti insediativi e manufatti: 101-129. Milán, Vita e Pensiero.

Cortés Tovar, R.; Balasch, M. (2008): Juvenal, Persio: Sátiras. Madrid, Gredos.

Coulon G. (2004): L'enfant en Gaule romaine. $2^{\mathrm{a}}$ ed. Paris, Errance, Hespérides.

Cuq, E. (1899a): "Infans", en M. Daremberg y M. Pottier (dirs.), Dictionnaire des Antiquités grecques et romaines d'après les textes et les monuments, vol. 3 : 485-488. Paris, Hachette.

Cuq, E. (1899b): "Infanticide”, en M. Daremberg y M. Pottier (dirs.), Dictionnaire des Antiquités grecques et romaines d'après les textes et les monuments, vol. 3 : 488-493. Paris, Hachette.

Dasen, V. (2009): "Roman birth rites of passage revisited". Journal of Roman Archaeology 22: 199-214.

Delgado A.; Ferrer, M. (2007): “Alimentos para los muertos: mujeres, rituales funerarios e identidades coloniales", en Interpreting household practices. Treballs d'Arqueologia 13: 29-68.

Díaz y Díaz, M. (1967): "En torno a los orígenes del Cristianismo hispánico", en Las raíces de España: 223-443. Madrid, Instituto Español de Antropología Aplicada.

D’Ors, A. (2009): Cicerón: Obras políticas. Sobre la República; Las Leyes. Madrid, Gredos.
Dupont, F. (1994): Le citoyen romain sous la République (509-27 av. J.-C.). Paris, Hachette.

Dupré i Raventós, X. (1987): "Una necropoli tardo-romana al futur parc de la ciutat de Tarragona". Espais 7: 32-35.

Fabião, C. (2004): “Centros oleiros da Lusitânia: Balanço dos conhecimentos e perspectivas de investigação", en Figlinae Baeticae. Talleres alfareros y producciones cerámicas en la Bética romana (ss. II a.C. - VII d.C.). B.A.R., Int. Ser. 1266: 379-410. Oxford, John and Erica Hedges Limited.

Fernández Ubiña, J. (1982): La crisis del siglo III y el fin del Mundo Antiguo. Madrid, Akal.

Fernández Ubiña, J. (2007): "Los orígenes del Cristianismo hispano. Algunas claves sociológicas". Hispania Sacra 59: 427-458.

Foguet, G.; Vilaseca, A. (1995): "Els enterraments dei carrer Prat de la Riba/Ramon y Cajal: un nou sector excavat de la necròpolis del Francolí”, en El món a l'antiguitat a la Catalunya Meridional. L'Arqueologia de la mort: el món funerari a l'antiguitat a la Catalunya meridional. Citerior 1: 151-171.

Fontán, A.; Moure Casas, A. M.; García Arribas, I. (2008): Plinio el Viejo: Historia Natural. Madrid, Gredos.

Frías Castillejo, C. (2012): "Villa Romana de l'Albir (L'Alfàs del Pi)". Publicación digital: Intervenciones arqueológicas en la provincia de Alicante: http://www.marqalicante.com/contenido/int_arqueologicas/doc_228.pdf(cons. 29/11/2017)

García Moreno, L. (2005): "El Cristianismo en las Españas: Los orígenes", en M. Sotomayor Muro y J. Fernández Ubiña (eds.), El Concilio de Elvira y su tiempo: 169-193. Granada, Universidad de Granada

García Noguera, M.; Remolà Vallverdú, J. (2000): "Noves intervencions a les necrópolis tardoantigues del marge esquerre del riu Francolí". Arqueologia d'una capital provincial romana. Documents d'Arqueologia Clàssica, 3: 165-180.

García Prósper, E. (2015): Los ritos funerarios de la necrópolis romana de la calle Quart de Valencia (siglos II a.C.-III d.C.). Tesis Doctoral, Universitat de Valencia, inédita.

García Prósper, E.; Polo Cerda, M.; Guérin, P. (20022003): "Rituales funerários ibéricos en la necrópolis fundacional de Valencia". Anales de Arqueología Cordobesa 13-14: 279-310.

García Vargas, E. (1998): La producción de ánforas en la Bahía de Cádiz en época romana (siglos II a. C.IV d.C.). Écija, Gráficas Sol. 
García Vargas, E.; Bernal Casasola, D. (2008): “Ánforas de la Bética”, en D. Bernal Casasola y A. Ribera i Lacomba (coords.), Cerámicas hispanorromanas: un estado de la cuestión. Actas del XXVI Congreso Internacional de la Asociación Rei Cretariae Romanae Fautores: 661-688. Cádiz (2008), Cádiz, Universidad de Cádiz.

Garnsey, P. (1991): "Child rearing in ancient Italy", en D. Kertzer y R. Saller (eds.), The family in Italy from Antiquity to the present: 48-65. New Haven, CT., Yale University Press.

Gisbert Santonja, J.; Senti Ribes, M. (1989): “Enterramientos infantiles fundacionales en el 'edificio horreum' y 'edificio occidental' del yacimiento romano de Dianium (Denia, Alicante)". Cuadernos de Prehistoria y Arqueología Castellonenses 14: 95-126.

Gómez Bellard, C.; Gómez Bellard, F. (1989): "Enterramientos infantiles en la Ibiza fenicio-púnica”. Cuadernos de Prehistoria y Arqueología Castellonenses 14: 211-238.

Gómez Bellard, F.; Miguel Ibáñez, P. (1997): “Inhumación fetal en la necrópolis de la villa romana "Casa Ferrer I", Alicante: avance de su estudio", en XXIV Congreso Nacional de Arqueología, Vol. 4: 525 530. Cartagena (1997), Murcia, Instituto de Patrimonio Histórico.

Gómez Marín, M.; Gil y Gómez, P. (1874): El Digesto del Emperador Juliano. Madrid, Imprenta de Ramón Vicente.

González Fernández, J. (2008): Plinio el Joven: Cartas. Madrid, Gredos.

González Gutiérrez, P. (2015): "Prostitutas y control de natalidad en el mundo grecorromano", en P. Hernández Rodríguez; G. Hernández Sánchez; P. Ortega Martínez; C. Píriz González y P. Poveda Arias (eds.), Amor y sexualidad en la Historia: 137-155. Salamanca, Hergar Ediciones Antema.

González Villaescusa, R. (2001): El mundo funerario romano en el País Valenciano. Monumentos funerarios y sepulturas entre los siglos I a.C. - VII d.C. Madrid/Alicante, Casa de Velázquez e Instituto Alicantino de Cultura.

Grubbs, J. (2013): "Infant Exposure and Infanticide", en J. Grubbs, J. y T. Parkin. (eds.), The Oxford Handbook of Childhood and Education in the Classical World: 83-97. Oxford, Oxford University Press.

Gurt Esparraguera, J.; Macias Solé, J. (2002): "La ciudad y el territorium de Tarraco: el mundo funerario", en D. Vaquerizo Gil (ed.), Espacio y usos funerarios en el Occidente romano. Actas del Congreso
Internacional, Vol. I: 87-112. Córdoba, Universidad de Córdoba.

Hanson A. (1990): “The medical Writer's Woman”, en D. Halperin; J. Winkler y F. Zeitlin (eds.), Before Sexuality: The Construction of Erotic Experience in the Ancient Greek World: 309-338. Princeton, Princeton University Press.

Harlow, M.; Laurense, R.; Voulanto, V. (2007): "Past, present and future in the study of Roman childhood", en S. Crawford y G. Shepherd (eds.), Children, childhood and society. BAR International Series, 1696: 5-14. Oxford, Archaeopress.

Hernández García, J. (1998): “La necrópolis tardorromana del Molino. Paganismo y cristianismo en un mismo espacio cementerial (Águilas, Murcia)". Memorias de Arqueología 13: 171-210.

Hernández Miguel, A. (1998): Varrón: La lengua Latina. Madrid, Gredos.

Hilberg, I. (1970): Sancti Eusebii Hieronymi Epistulae. New York [etc.], Johnson Reprint.

Hope, V. (2009): Roman death: dying and the dead in ancient Rome. London, Bloomsbury Academic.

Hopkins, K. (1966): “On the probable age structure of the Roman population". Population Studies 20: 254-64.

Infantas Beato, G.; Puerto Fernández, J. (2010): “Actividad arqueológica preventiva en la necrópolis del Faro de Torrox (Málaga)". Anuario Arqueológico de Andalucía 2006: 3485-3497.

Kampen, N. B. (1981): "Biographical Narration and Roman Funerary Art". American Journal of Archaeology 85, 1: 47-58.

Kollia, M. " M. (2013): "Les 3000 bébés d'Astypalée". Dossiers d'Archéologie 356: 22-29.

Lagóstena Barrios, L. (2001): La producción de salsas y conservas de pescado en la Hispania romana. Col·lecció Instrumenta 11. Barcelona, Universidad de Barcelona.

Laiz Reverte, M.; Berrocal Caparrós, M. (1995): “Elementos para la datación cronológica de la necrópolis paleocristiana de San Antón en Cartagena". IV Reunió D`Arqueologia Cristiana Hispànica: 163172. Lisboa (1992), Barcelona, Institut d'Estudis Catalans-Universitat de Barcelona.

Langer, W. (1974): "Infanticide: A historical survey". History of Childhood Quarterly 1: 353-365.

Laubenheimer, F. (2004): "La mort des tout-petits dans l'Occident romain", en V. Dasen (ed.), Naissance et petite enfance dans l'Antiquité: 293-315. Fribourg, Academic Press / Göttingen, Vandenhoeck \& Ruprecht. 
Lewis, M. (2011): "The Osteology of Infancy and Childhood: misconceptions and potential", en M. Lally y A. Moore (eds), (Re)Thinking the Little Ancestor: New Perspectives on the Archaeology of Infancy and Childhood. BAR International Series 2271: 1-13. Oxford, Archaeopress.

Lillo Carpio, P. (2001-2002): "Notas acerca de la incineración". Anales de Prehistoria y Arqueología 17-18: 127-146.

Lindsay, H. (2000): "Death-pollution and funerals in the city of Rome", en V. Hope y E. Marshall (eds.), Death and disease in the ancient city: 152-172. London, Routledge.

López Domínguez, M.; Castilla Reyes, E.; Haro Ordóñez, J. (2006): “Intervención arqueológica puntual de apoyo a la restauración en el mausoleo romano de la Punta del Moral (Ayamonte, Huelva)". Anuario Arqueológico de Andalucía 2003. 2: 236-246.

López Melero, R. (1997): “Enterrar en Urso (Lex Ursonensis LXXIII-LXXIV)”. Studia Histórica 15-16: 105-118.

Matos, J. de (1985): Cerro da Vila. Campanha de trabalhos arqueológicos. Relatório técnico, Lisboa. Direcção Geral do Património Cultural.

Medina González, A. (2009): Cicerón: Obras filosóficas, II, Disputaciones Tusculanas. Madrid, Gredos.

Melero García, F. (2009): "Descubrimiento de una nueva secuencia fenicia completa en los solares $\mathrm{n}^{\circ}$ 9-11 de la c/ Tiro, esq . c/ Zamorano, (Barrio de la Trinidad, Málaga)". Anuario Arqueológico de Andalucía 2004.1: 2430-2440.

Monsieur, P. (2007): “Amphora Burials and Burials with Amphorae: on the Reuse of Amphorae in the Northern Necropolis of Potentia (Porto Recanati, Marche)", en B. Croxford; N. Ray; R. Roth y N. White (eds.), TRAC 2006: Proceedings of the Sixteenth Annual Theoretical Roman Archaeology Conference: 133-149. Oxford: Oxbow Books.

Moralejo, J. L. (2007): Horacio: Odas; Canto secular; Epodos. Madrid, Gredos.

Morales Otal, C.; García López, J. (2001): Plutarco: Obras morales y de costumbres. 2 vols. Madrid, Gredos.

Moreno Romero, L. (2006): "Manifestaciones funerarias de época altoimperial en Colonia Patricia". Anales de Arqueología Cordobesa 17: 225-258.

Muñoz Vicente, A.; García Jiménez, I.; Prados Martínez, F. (2009): "Espacios jerarquizados y áreas funerarias en la necrópolis oriental de Baelo Claudia (Tarifa, Cádiz). Nuevas perspectivas de estudio", en Catálogo de la exposición Jorge
Bonsor y la recuperación de Baelo Claudia (19171921): 59 - 77. Sevilla, Junta de Andalucía.

Néraudau, J.-P. (1979): La jeunesse dans la littérature et les institutions de la Rome républicaine. Paris, Les Belles Lettres.

Néraudau, J.-P. (1984): Être enfant à Rome. Paris, Les Belles Lettres.

Norman, N. (2002): "Death and burial of Roman Children: the case of the Yasmina Cemitery at Carthage - Part I, setting the stage". Mortality 7. 3: 302-323.

Norman, N. (2003): "Death and burial of Roman children: the case of the Yasmina Cemitery at Carthage - Part I, the archaeological evidence". Mortality 8. 1: $36-47$.

Penco Valenzuela, F. (1998): "Un conjunto funerario de libertos y esclavos de época altoimperial excavado en la calle El Avellano, $\mathrm{n}^{\circ} 12$ de Córdoba. Una nueva aportación a Colonia Patricia Corduba". Antiquitas 9: 61-77.

Pereira, C. (2014a): As necrópoles romanas do Algarve. Acerca dos espaços da morte no Extremo Sul da Lusitânia. Tesis doctoral, Universidad de Lisboa, inédito.

Pereira, C. (2014b): "Reflexiones sobre el decaer del comercio de lucernas romanas en el Occidente peninsular". Onoba, Revista de Arqueología y Antigüedad 2: 191-206.

Prados Martínez, F. (2015): "El ritual funerario en Baelo Claudia durante el alto imperio (ss. I-II d.C.)", en Prados Martínez, F.; Jiménez Vialás, H. (eds.), La muerte en Baelo Claudia. Necrópolis y ritual en el confin del Imperio Romano: 107-124. Cádiz, Universidad de Cádiz.

Prados Martínez, F.; Jiménez Vialás, H. (2016): “La materialidad de la muerte en la necrópolis de Baelo Claudia. Ritos y creencias en contexto". Archivo Español de Arqueología 89: 273-291.

Prioreschi, P. (1995): "Contraception and Abortion in the Greco-Roman World". Vesalius 1. 2: 77-87.

Pugsley, P. (2003): Roman domestic wood. Analysis of the morphology, manufacture and use of selected categories of domestic wooden artefacts with particular reference to the material from Roman Britain. BAR Int. Series 1118. Oxford, John and Erika Hedges Limited.

Ramos Pasalodos, J. J. (2001): Tertuliano: Acerca del Alma. Madrid, Akal.

Rawson, B. (1997): "The iconography of Roman childhood", en B. Rawson y P. Weaver (eds.), The Roman family in Italy: status, sentiment, space: 125132 Oxford, Clarendon Press. 
Ribera i Lacomba, A. (2010): "Depositos rituales de Valentia (Hispania). De la primera fundación republicana (138 a.C.) a la segunda augustea", en I riti del costruire nelle acque violate. Atti del Convegno Internazionale: 269-294. Roma, Scienze e lettere.

Rose, H. J. (1923): "Nocturnal funerals in Rome". The Classical Quarterly 17 (3/4): 191-194.

Ruiz Osuna, A. (2009): Topografía y monumentalización funeraria en Baetica: conventus Cordubensis y Astigitanus. Tesis Doctoral, Universidad de Córdoba. Inédita.

Sánchez Sánchez, G. (2001): “Ejemplo de continuidad en un espacio funerario de Mérida. Intervención arqueológica en un solar s/n de la $\mathrm{C} /$ Travesía Marquesa de Pinares". Memoria 5: 49-84.

Sánchez Ramos, I. (2006): La cristianización de la topografia funeraria en las provincias occidentales del Imperio: exemplum cordubense. Cordoba, Edita.

Santos Gener, S. (1955): Memoria de las excavaciones del Plan Nacional, realizadas en Córdoba (19481950). Madrid, Ministerio de Educación Nacional, Comisaría General de Excavaciones Arqueológicas.

Serrano Ramos, E. (2006): “Aproximación a las necrópolis de época romana en el territorio malagueño". Baetica 28: 159-174.

Serrano Ramos, E.; Baldomero Navarro, A.; Martín Ruiz, J. (1993): "Necrópolis romana del Castillo de San Luis (Torremolinos, Málaga)". Baética 15: 207-216.

Sibón Olano, F.J.; Gómez Fernández, V.; Niveau de Villedary y Mariñas, A. (2007): “Intervención arqueológica de urgencia en el solar de la futura "Ciudad de la Justicia" (Cádiz)". Anuario Arqueológico de Andalucía 2004.2: 148-158.

Slim, L. (1983): “A propos d'un cimitière d'enfants à Thysdrus", en A. Mastino (ed.), L'Africa Romana. Atti del I Convegno di Studio: 167-177. Sassari (1983), Venezia, Edizioni Gallizzi.

Smith, P.; Kahila, G. (1992): "Identification of Infanticide in Archaeological Sites: A Case Study from the Late Roman-Early Byzantine Periods at Ashkelon, Israel". Journal of Archaeological Science 19: 667-675.

Stevens, S. (2013): "Stages of infancy in Roman amphora burial", en J. Grubbs y T. Parkin (eds.), The Oxford Handbook of Childhood and Education in the Classical World: 627-643. Oxford, Oxford University Press.

TED'A (Dupré i Raventós, X. et al.) (1987): Els enterraments del Parc de la Ciutat i la problemàtica funerària de Tàrraco. Memòries d'excavació, 1. Tarragona, Ayuntamiento de Tarragona.
Teichner, F.; Schierl, T.; Gonçalves, A.; Tavares, P. (2007): "Sebastião Philippes Martins Estácio da Veiga e as necrópoles romanas de Ossonoba (Faro)". Xelb 7: 159-178.

Tinoco Muñoz, J. (2004): "Informe de la I.A.U. en el sector E-38. 1" fase, residencial "La Algodonera" de Écija, Sevilla". Anuario Arqueológico de Andalucía 2001.2: 908-919.

Toynbee, J. (1996): Death and Burial in the Roman World. Baltimore, London, The Johns Hopkins University Press.

Ulrich, R. (2007): Roman Woodworking. Yale, University Press.

Vaquerizo Gil, D. (2001): "Formas arquitectónicas funerarias de carácter monumental en Colonia Patricia Corduba". Archivo Español de Arqueología 74: 131-160.

Vaquerizo Gil, D. (2007): "La muerte en la Hispania Romana: ideología y prácticas”, en J. Barca y J. Jiménez Ávila (eds.), Enfermedad, muerte y cultura en las sociedades del pasado. Importancia de la contextualización en los estudios paleopatológicos, Actas del VIII Congreso Nacional de Paleopatología, Vol. I: 135-158. Cáceres, Fundación Academia Europea de Yuste.

Vaquerizo Gil, D. (2010): Necrópolis urbanas en Baetica. Documenta 15. Sevilla/Tarragona, Universidad de Sevilla e Institut Català d'Arqueologia Clàssica.

Vargas Cantos, S. (2002): "El conjunto funerario de La Constancia (Córdoba). Ajuares y cronología”, en D. Vaquerizo Gil (ed.), Espacio y usos funerarios en el Occidente Romano, Vol. II: 297-310. Córdoba, Universidad de Córdoba

Vegas Sansalvador, A. (1987): Jenofonte: Ciropedia. Madrid, Gredos.

Vidal Teruel, N.; Campos Carrasco, J. (2006): "Las necrópolis de Onoba". Anales de Arqueología Cordobesa 17.2: 13-34.

Vlachou, V. (2007): “Oropos: the infant and child inhumations from the settlement (late 8th-early 7 th centuries BC)", en Ainian, A. (ed.), Oropos and Euboea in the early Iron Age: 213-240. Volos, University of Thessaly Press.

Wallace-Hadrill, A. (2008): "Housing the Dead: the tomb as house in Roman Italy", en L. Brink y D. Green (eds), Commemorating the dead. Texts and artifacts in context. Studies of Roman, Jewish, and Christian burials: 39-77. Berlín, Walter de Gruyter. 